\title{
Heterolytic $\mathrm{H}_{2}$ Cleavage and Catalytic Hydrogenation by an Iron Metallaboratrane
}

\author{
Henry Fong, Marc-Etienne Moret ${ }^{\dagger}$, Yunho Lee $^{\ddagger}$, and Jonas C. Peters ${ }^{\star}$ \\ Division of Chemistry and Chemical Engineering, California Institute of Technology, Pasadena, \\ CA 91125, USA
}

\begin{abstract}
Reversible, heterolytic addition of $\mathrm{H}_{2}$ across an iron-boron bond in a ferraboratrane with formal hydride transfer to the boron gives iron-borohydrido-hydride complexes. These compounds catalyze the hydrogenation of alkenes and alkynes to the respective alkanes. Notably, the boron is capable of acting as a shuttle for hydride transfer to substrates. The results are interesting in the context of heterolytic substrate addition across metal-boron bonds in metallaboratranes and related systems, as well as metal-ligand bifunctional catalysis.
\end{abstract}

\section{Keywords}

Metallaboratrane; non-noble metal hydrogenation catalysis; heterolytic dihydrogen activation

\section{INTRODUCTION}

Transition metal-catalyzed bond forming reactions often involve formal two-electron redox steps (e.g., oxidative addition and reductive elimination). Noble metal catalysts are commonly used in these reactions due, in part, to their propensity to facilitate multi-electron processes. ${ }^{1}$ There is growing interest in developing catalysts for bond forming/cleavage reactions based on earth abundant mid-to-late first-row transition metals, a goal that presents a unique set of challenges. ${ }^{2}$ First-row transition metal catalysts that can circumvent undesirable one electron processes in favor of concerted two electron reaction steps present one plausible design criterion. ${ }^{3}$

Cooperative catalysis strategies that utilize ligands that operate in tandem with a coordinated metal center to activate substrates have shown promise in addressing this issue. ${ }^{4,5}$ First-row metallaboratranes and related compounds that contain a retrodative $\mathrm{M} \rightarrow \mathrm{B} \sigma$-interaction ${ }^{6}$ are appealing as catalysts ${ }^{7}$ because of the boron center's ability to stabilize low valent metals. ${ }^{8}$ Akin to frustrated Lewis pairs, ${ }^{9}$ it has also been recently demonstrated that the metal-boron interaction can cooperatively facilitate the activation of $\mathrm{H}_{2} \cdot{ }^{5,7}$ For instance, our lab recently reported that the diphosphine-borane nickel $\left({ }^{\mathrm{Mes}} \mathrm{DPB}^{\mathrm{Ph}}\right) \mathrm{Ni}$ complex undergoes reversible oxidative addition of $\mathrm{H}_{2}$ to afford a nickel-borohydrido-hydride complex (Scheme 1). ${ }^{10}$ This

\footnotetext{
*Corresponding Author: jpeters@ caltech.edu.

$\dagger$ Organic Chemistry and Catalysis Group, Faculty of Science, Utrecht, Universiteitsweg 99, 3584 CG Utrecht, The Netherlands; m.moret@uu.nl

‡Department of Chemistry, School of Molecular Science, Korea Advanced Institute of Technology, 291 Daehak-ro Yuseong-gu, Daejeon 305-701, Republic of Korea; yunholee@kaist.ac.kr

The authors declare no competing financial interests.

Supporting Information. Spectral data, catalysis data, computational details, solid state structures $\left(\mathbf{4}\right.$ and $\left.\left(\mathbf{S i P}^{i \mathbf{P r}} \mathbf{3}\right) \mathbf{F e}(\mathbf{C O})(\mathbf{H})\right)$, and CIF files (for 2, 3, 4, 5, 8, 10, 11, and $\left(\operatorname{SiP}^{i P r_{3}}\right) \mathbf{F e}(\mathbf{C O})(\mathbf{H})$ ). This material is available free of charge via the Internet at http:// pubs.acs.org.
} 
nickel system is an efficient catalyst for olefin hydrogenation. Kameo and Nakazawa have also reported on the transfer hydrogenation of ketones catalyzed by a rhodium diphosphineborane complex. ${ }^{11}$

Herein we report on studies of heterolytic $\mathrm{H}-\mathrm{H}$ bond cleavage at a ferraboratrane complex ${ }^{12}$ of a triphosphine-borane (TPB) ligand. ${ }^{13}$ Dihydrogen is shown to add reversibly across the Fe-B bond of (TPB)Fe(L) complexes to form corresponding iron-borohydrido-hydride complexes of the type (TPB) $(\mu-\mathrm{H}) \mathrm{Fe}(\mathrm{L})(\mathrm{H})$. Like the nickel system reported previously, olefin hydrogenation catalysis is accessible, albeit much slower, thereby facilitating detailed studies. As discussed below, other E-H bonds are also activated by the ferraboratanes described, including the terminal $\mathrm{C}-\mathrm{H}$ bonds of arylacetylenes and the $\mathrm{C}-\mathrm{H}$ bonds of formaldehyde.

\section{RESULTS AND DISCUSSION}

\section{Reversible $\mathrm{H}_{2}$ Addition}

Exposing the previously reported (TPB)Fe $\left(\mathrm{N}_{2}\right)$ complex $^{12 \mathrm{a}}(\mathbf{1})$ in $d_{6}$-benzene to $\mathrm{H}_{2}(1.2$ equiv) at room temperature results in $\mathrm{H}_{2}$ addition across the $\mathrm{Fe}-\mathrm{B}$ bond to give a yellow solution of the six coordinate borohydride-hydride- $\mathrm{N}_{2}$ complex $(\mathrm{TPB})(\mu-\mathrm{H}) \mathrm{Fe}\left(\mathrm{N}_{2}\right)(\mathrm{H})(2)$ (Scheme 2, Figure 1). The XRD structure of $\mathbf{2}$ shows that the Fe-B distance is significantly elongated relative to $\mathbf{1}$ (2.604(3) $\AA$ in $\mathbf{2}$ versus the calculated distance of $2.2 \AA$ in $\mathbf{1}^{12 b}$ ) (Figure 1). A terminal hydride ligand and a bridging hydride ligand located between the $\mathrm{B}$ and $\mathrm{Fe}$ atoms can be assigned from the electron density difference map. This structure also prevails in solution. In the ${ }^{1} \mathrm{H}$ NMR spectrum ( $d_{6}$-benzene), the terminal hydride ligand on iron is observed as a triplet-of-doublets at $-9.6 \mathrm{ppm}$, and the bridging hydride is observed as a broad singlet at $-30.4 \mathrm{ppm}$. Replacing $\mathrm{H}_{2}$ with $\mathrm{D}_{2}$ in the reaction gives the corresponding isotopologue (TPB)( $\mu-\mathrm{D}) \mathrm{Fe}\left(\mathrm{N}_{2}\right)(\mathrm{D})$. Along with the expected deuteride signals in the ${ }^{2} \mathrm{H}$ NMR spectrum, deuterium signals from the methine and terminal methyl positions of the isopropyl groups of the TPB ligand are observed. This observation establishes that facile scrambling of the hydridic ligands into the TPB isopropyl groups occurs, presumably via a reversible $\mathrm{C}-\mathrm{H}$ metalation process.

The dinitrogen ligand $\left(\nu_{\mathrm{NN}}=2070 \mathrm{~cm}^{-1}\right)$ in $\mathbf{2}$ is labile, and it can be substituted under excess $\mathrm{H}_{2}$ to give the dihydrogen analogue (TPB) $(\mu-\mathrm{H}) \mathrm{Fe}\left(\mathrm{H}_{2}\right)(\mathrm{H})(\mathbf{3})$ (Scheme 2). Exposing 1 to excess $\mathrm{H}_{2}(1 \mathrm{~atm})$ also generates 3 . Its XRD structure again confirms the presence of a bridging hydride (Figure 2). Although electron density can be located in the difference map between a widened P-Fe-P angle $\left(136.54(2)^{\circ}\right)$ and in the apical position trans to the borohydride unit, the data do not allow us to reliably distinguish between classical and nonclassical hydrides. We therefore turned to NMR spectroscopy to aid in the formulation of $\mathbf{3}$.

The $20{ }^{\circ} \mathrm{C}{ }^{1} \mathrm{H}$ NMR spectrum ( $d_{8}$-toluene) of $\mathbf{3}$ (Figure 3) shows a broad singlet resonance at $-15.1 \mathrm{ppm}$, indicative of hydridic protons. A broad deuteride signal is observed in the ${ }^{2} \mathrm{H}$ NMR spectrum when $\mathrm{D}_{2}$ is used in place of $\mathrm{H}_{2}$, and, like in 2, deuterium signals are also observed in the methyl and methine positions of the isopropyl groups of the TPB ligand. Cooling a $d_{8}$-toluene solution of $\mathbf{3}$ under an $\mathrm{H}_{2}$ atmosphere to $-20{ }^{\circ} \mathrm{C}$ leads to sharpening of the resonance at $-15.1 \mathrm{ppm}$, which integrates to three protons $(3 \mathrm{H})$. A second, broad hydridic resonance integrating to one proton is also observed at $-24.9 \mathrm{ppm}$, and in analogy to 2 , this resonance is assigned to the bridging-borohydride $(\mu-\mathrm{H})$. Cooling down to $-90^{\circ} \mathrm{C}$ leads to broadening of the $3 \mathrm{H}$ resonance without reaching decoalescence, suggesting that exchange of three hydrogenic ligands is fast on the NMR timescale. Compound $\mathbf{3}$ can be heated to $50{ }^{\circ} \mathrm{C}$ before significant sample decomposition is observed (vide infra). At $50{ }^{\circ} \mathrm{C}$, the $3 \mathrm{H}$ and $\mu-\mathrm{H}$ signals both broaden into the baseline, suggesting that exchange of all four hydrogens is facile at this temperature. 
To further assign the $3 \mathrm{H}$ unit in $\mathbf{3}$ (i.e. dihydrogen-hydride versus trihydride), we turned to minimal longitudinal relaxation $\left(\mathrm{T}_{1 \mathrm{~min}}\right)$ measurements. ${ }^{14,15} \mathrm{The} \mathrm{T}_{1 \mathrm{~min}}$ is $35 \mathrm{~ms}$ at $-32{ }^{\circ} \mathrm{C}$ for the $3 \mathrm{H}$ resonance, which suggests that the $3 \mathrm{H}$ unit is best described as dihydrogenhydride and implying the following assignment for 3: (TPB) $(\mu-\mathrm{H}) \mathrm{Fe}\left(\mathrm{H}_{2}\right)(\mathrm{H})$. This interpretation is additionally supported by DFT calculations (RB3LYP/6-31G(d)) that identify a dihydrogen-hydride structure (Figure 2 and Supporting Information) as the lowest energy isomer of 3 . A stereoisomer in which the $\mathrm{H}_{2}$ ligand occupies the equatorial position and the hydride ligand is in the axial position trans to boron is calculated to be $6.1 \mathrm{kcal} / \mathrm{mol}$ higher in energy. This geometric preference parallels that of the well-characterized irondihydrogen-dihydride complex mer-Fe $\left(\mathrm{H}_{2}\right)(\mathrm{H})_{2}\left(\mathrm{PEt}_{2} \mathrm{Ph}\right)_{3} \cdot{ }^{16}$ The transition state for conversion of $\mathbf{3}$ into this higher energy stereoisomer involving $\mathrm{H}-\mathrm{H}$ scission is calculated to be $6.7 \mathrm{kcal} / \mathrm{mol}$ above the most stable isomer and is in line with the observed exchange behavior on the NMR timescale.

Analogous (TPB) $(\mu-\mathrm{H}) \mathrm{Fe}(\mathrm{L})(\mathrm{H})$ complexes $\left(\mathrm{L}=\mathrm{CN}^{t} \mathrm{Bu}(\mathbf{5}), \mathrm{CO}(\mathbf{7})\right)$ can be synthesized (Scheme 2, Figure 1). To explore the effect of the apical ligand $\mathrm{L}$ on the $\mathrm{H}-\mathrm{H}$ bond activation process, $(\mathrm{TPB}) \mathrm{Fe}(\mathrm{L})$ complexes $\left(\mathrm{L}=\mathrm{CN}^{t} \mathrm{Bu}, 4 ; \mathrm{L}=\mathrm{CO}, \mathbf{6}\right)$ were prepared. The previously reported carbonyl complex 6 displays an $\eta^{3}$-interaction with a $\mathrm{P}-\mathrm{C}_{\mathrm{Ar}}-\mathrm{C}_{\mathrm{Ar}}$ unit of the TPB ligand ${ }^{12 \mathrm{a}}$ whereas isocyanide adduct $\mathbf{4}$, whose structure has been determined, does not: its Fe center is rigorously 5-coordinate. Complex $\mathbf{6}$ is diamagnetic whereas $\mathbf{4}$ gives rise to a solution magnetic susceptibility $\left(\mu_{\mathrm{eff}}=1.7 \mu_{\mathrm{B}}\right)$ at room temperature in $\mathrm{C}_{6} \mathrm{D}_{6}$. The temperature dependence of the solution susceptibility suggests an $S=0$ ground state with a thermally accessible $S=1$ state. No reaction occurs between $(\mathrm{TPB}) \mathrm{Fe}\left(\mathrm{CN}^{t} \mathrm{Bu}\right)\left(\mathbf{4}, \mu_{\mathrm{eff}}=1.7\right.$ $\left.\mu_{\mathrm{B}}\right)$ or the previously reported $(\mathrm{TPB}) \mathrm{Fe}(\mathrm{CO})^{12 \mathrm{a}}(\mathbf{6})$ with $\mathrm{H}_{2}(1 \mathrm{~atm})$ at room temperature over a period hours. Compound 4 is fully consumed by $\mathrm{H}_{2}$ (1 atm) over the course of 3 days at $40{ }^{\circ} \mathrm{C}$ to generate $\mathbf{5}$, while compound $\mathbf{6}$ is fully consumed by $\mathrm{H}_{2}(1 \mathrm{~atm})$ over the course of 5 days at $80^{\circ} \mathrm{C}$ to give 7 . The increase in temperature and reaction time compared to the facile room temperature reaction between 1 and $\mathrm{H}_{2}$ is consistent with a scenario in which $\mathrm{H}_{2}$ substitution for $\mathrm{L}$ occurs prior to $\mathrm{H}_{2}$ addition across the Fe-B bond. Complex 7 can be alternatively synthesized from $\mathbf{1}$ or $\mathbf{2}$ and formaldehyde (Scheme 2).

Dihydrogen addition across the Fe-B bond of $\mathbf{1}$ is reversible. Conversion of $\mathbf{3}$ to $\mathbf{2}$ and subsequently back to 1 can be effected by exposing 3 to dynamic vacuum and then $\mathrm{N}_{2}$, or by repeated freeze-pump-thaw- $\mathrm{N}_{2}$ cycles. Reformation of the Fe-B bond can also occur through hydride transfer to unsaturated substrates (vide infra). Dihydrogen elimination from $\mathbf{5}$ and $\mathbf{7}$ does not occur when treated similarly.

Worth underscoring is that cleavage of the Fe-B bond in the present ferraboratrane system is distinct from the $\mathrm{H}_{2}$ chemistry observed for a structurally related ( $\left.\mathrm{SiP}^{2 P r}{ }_{3}\right) \mathrm{Fe}$ silatrane system $\left(\mathrm{SiP}_{3} \mathrm{Pr}_{3}=\left[\mathrm{Si}\left(o-\mathrm{C}_{6} \mathrm{H}_{4} \mathrm{P}^{I P r}{ }_{2}\right)_{3}\right]^{-}\right.$, ) we have introduced elsewhere. ${ }^{17,18,19}$ For instance, the reaction between $\left(\mathrm{SiP}_{3}{ }_{3}\right) \mathrm{Fe}\left(\mathrm{N}_{2}\right)$ and $\mathrm{H}_{2}$ affords $\left(\mathrm{SiP}_{3} \mathrm{Pr}_{3}\right) \mathrm{Fe}\left(\mathrm{H}_{2}\right)$, and that between $\left[\left(\mathrm{SiP}_{3}{ }_{3}\right) \mathrm{Fe}\left(\mathrm{N}_{2}\right)\right]^{+}$and $\mathrm{H}_{2}$ affords $\left[\left(\mathrm{SiP}_{3}^{I P r}\right) \mathrm{Fe}\left(\mathrm{H}_{2}\right)\right]^{+}$. No disruption of the $\mathrm{Fe}-\mathrm{Si}$ bond is observed in either case, even if for instance isolated $\left[\left(\mathrm{SiP}_{3} \mathrm{Pr}_{3}\right) \mathrm{Fe}\left(\mathrm{N}_{2}\right)\right]^{+}$or $\left[\left(\mathrm{SiP}^{2} \mathrm{Pr}_{3}\right) \mathrm{Fe}\left(\mathrm{H}_{2}\right)\right]^{+}$ is exposed to excess $\mathrm{H}_{2}$. Ligand substitution instead occurs. This sharply contrasts isoelectronic (TPB)Fe( $\left.\mathrm{N}_{2}\right) \mathbf{1}$, where $\mathrm{H}_{2}$ addition readily affords the cleavage product $\mathbf{2}$ or $\mathbf{3}$. We also find (this report, Scheme 3 ) that hydrogenolysis of the iron(II) methyl complex $\left(\mathrm{SiP}_{3}{ }_{3} \mathrm{Pr}\right) \mathrm{Fe}(\mathrm{Me})$ occurs slowly at $60{ }^{\circ} \mathrm{C}$ to give an $\mathrm{H}_{2} / \mathrm{H}$ product, but once again without disruption of the Fe-Si bond. Addition of exogenous donor ligands such as $\mathrm{H}_{2}, \mathrm{~N}_{2}$ and $\mathrm{CO}$ effects substitution of the coordinated $\mathrm{H}_{2}$ ligand, but the $\mathrm{Fe}-\mathrm{Si}$ bond is maintained. One factor contributing to the difference between the two systems is likely the more flexible Fe$\mathrm{B}$ bond in the (TPB)Fe system, as reflected in the variable Fe-B bond distances (varying by ca. $0.5 \AA)^{12 b}$ versus more rigid Fe-Si bond distances (varying by ca. $\left.0.2 \AA\right)^{17,18,19}$ in $\left(\mathrm{SiP}_{3}^{i \mathrm{Pr}}{ }_{3}\right) \mathrm{Fe}$ that have been observed over several formal iron oxidation states. The rigidity of 
the Fe-Si interaction presumably reflects an appreciably stronger Fe-Si bond relative to $\mathrm{Fe}$ B. One can additionally consider the relative Lewis acidity of the $\mathrm{Ar}_{3} \mathrm{~B}$ versus the $\mathrm{Ar}_{3} \mathrm{Si}^{+}$ subunit ${ }^{18}$ in these respective systems, and their propensity to serve as $\mathrm{H}^{-}$acceptors, but one might then predict the $\mathrm{Ar}_{3} \mathrm{Si}^{+}$to be the better acceptor, in contrast to the experimental observations. Indeed, this latter point may be the reason the Fe-Si interaction is stronger than the Fe-B interaction.

\section{Reaction with Unsaturated Substrates}

The ability of the (TPB)Fe scaffold to reversibly cleave $\mathrm{H}_{2}$ prompted us to study if the transfer of hydrogen from $(\mathrm{TPB})(\mu-\mathrm{H}) \mathrm{Fe}(\mathrm{L})(\mathrm{H})$ to substrates is possible. The reaction of $\mathbf{1}$ with ethylene, styrene and arylacetylenes was probed. A degassed $d_{6}$-benzene solution of $\mathbf{1}$ reacts with ethylene to give a light brown solution of the paramagnetic iron-ethylene adduct (TPB)Fe $\left(\mathrm{C}_{2} \mathrm{H}_{4}\right)\left(\mathbf{8} ; \mu_{\mathrm{eff}}=3.2 \mu_{\mathrm{B}}, S=1\right)($ Scheme 4$)$. Brown XRD quality crystals of $\mathbf{8}$ can be grown under an atmosphere of ethylene at $0{ }^{\circ} \mathrm{C}$. Two molecules of 8 are found in the asymmetric unit cell. The iron center is bound $\eta^{2}$ to ethylene $\left((\mathrm{Fe}-\mathrm{C})_{\mathrm{avg}}=2.108(1) \AA\right)$ and lies above the plane defined by the phosphine donors by an average distance of $0.641 \AA$, with a corresponding elongation of the average Fe-B distance to 2.491(2) $\AA$ (compared to $2.2 \AA$ in 1). The average C-C bond distance $\left((C-C)_{a v g}=1.397(2) \AA\right)$ of the $\eta^{2}$-coordinated ethylene molecule is significantly elongated from that in free ethylene $(1.337 \AA) .{ }^{20}$ The data are consistent with $\pi$-backbonding from iron to ethylene, which confers significant ferracyclopropane character to $8 .^{21}$ Storing 8 for two days under an atmosphere of $\mathrm{N}_{2}$ fully regenerates $\mathbf{1}$.

Compound 1 does not afford a detectable styrene adduct but reacts with both phenyl- and tolylacetylene with formal hydride transfer from the terminal $\mathrm{C}(\mathrm{sp})-\mathrm{H}$ of the arylacetylene to the boron, forming $S=2$ iron-borohydrido-arylacetylide complexes $(\mathrm{TPBH}) \mathrm{Fe}\left(\mathrm{C}_{2} \mathrm{Ar}\right)(\mathrm{Ar}=$ $\left.\mathrm{Ph}, \mathbf{9}, \mu_{\mathrm{eff}}=5.1 \mu_{\mathrm{B}} ; \mathrm{Ar}=\mathrm{Tol}, \mathbf{1 0}, \mu_{\mathrm{eff}}=5.2 \mu_{\mathrm{B}}\right)($ Scheme 4). Two molecules of $\mathbf{1 0}$ are found in the asymmetric unit, and the XRD structure shows the presence of a tolylacetylide ligand coordinated to a pyramidalized iron center (Figure 4). While the hydride on the boron cannot be reliably located by XRD, the IR spectra for both $\mathbf{9}$ and $\mathbf{1 0}$ show B-H stretches at $2490 \mathrm{~cm}^{-1}$ and $2500 \mathrm{~cm}^{-1}$, respectively, most consistent with a non-bridging B-H unit. The vibrational bands shift to $1826 \mathrm{~cm}^{-1}$ (predicted $1834 \mathrm{~cm}^{-1}$ ) for 9 and $1824 \mathrm{~cm}^{-1}$ (predicted $\left.1841 \mathrm{~cm}^{-1}\right)$ for 10 upon labeling with the monodeuterated arylacetylene $(\operatorname{ArC} \equiv C D)$.

The activation of the arylacetylene $\mathrm{C}(\mathrm{sp})$ - $\mathrm{H}$ bond by $\mathbf{1}$ is reversible. Mixing a $d_{6}$-benzene solution of 9 with tolylacetylene (4 equiv) and, conversely, mixing a $d_{6}$-benzene solution of $\mathbf{1 0}$ with phenylacetylene (4 equiv) both result in a mixture of $\mathbf{9}$ and $\mathbf{1 0}$ (Scheme 5A). The corresponding exchange reactions with B-D labelled isotopologues of 9 or $\mathbf{1 0}$ $\left((\mathrm{TPBD}) \mathrm{Fe}\left(\mathrm{C}_{2} \mathrm{Ar}\right)\right)$ and a different all-protio arylacetylene $\left(\mathrm{Ar}{ }^{\prime} \mathrm{C} \equiv \mathrm{CH}\right)$ result in the exclusive formation of free $\mathrm{ArC} \equiv \mathrm{CD}$, indicating that the arylacetylene unit is reductively eliminated from the iron-borohydrido-arylacetylide complexes prior to activation of an incoming acetylene substrate, presumably by reversible hydride transfer from the boron to the arylacetylide to form intermediate $\pi$-adducts akin to $\mathbf{8}$ (Scheme $5 \mathrm{~B}$ ).

\section{Stoichiometric Hydrogenations}

We also explored whether the transfer of hydrogen from $(\mathrm{TPB})(\mu-\mathrm{H}) \mathrm{Fe}(\mathrm{L})(\mathrm{H})$ species to unsaturated substrates might be possible. Exposing 8 to excess $\mathrm{H}_{2}(1 \mathrm{~atm})$ results in complete conversion of ethylene to ethane and $\mathbf{3}$ as the iron-containing product (Scheme 6-i) in less than $12 \mathrm{~h}$. A paramagnetic intermediate (A) and $\mathbf{8}$ can be observed by in situ ${ }^{1} \mathrm{H}$ NMR spectroscopy. The same paramagnetic intermediate $\mathbf{A}$ and $\mathbf{8}$ can also be observed by in situ ${ }^{1} \mathrm{H}$ NMR spectroscopy if the same reaction is run under ethylene (1 atm) and $\mathrm{H}_{2}(1$ $\mathrm{atm})$. The IR spectrum of the reaction mixture shows a diagnostic terminal B-H vibration at 
$2470 \mathrm{~cm}^{-1}$ that is attributed to $\mathbf{A}$. Akin to the iron-borohydrido-alkynyl complexes $\mathbf{9}$ and $\mathbf{1 0}$, $\mathbf{A}$ is assigned to the iron-borohydrido-ethyl complex (Scheme 6-i). ${ }^{22}$ Using $\mathrm{D}_{2}$ in place of $\mathrm{H}_{2}$ in the ethylene hydrogenation reaction and monitoring leads to the observation of both B-D and B-H stretches in the IR spectrum, which is consistent with facile insertion/ $\beta$ hydride elimination processes prior to ethane elimination from $\mathbf{A}$. We note the similarity of A (and $\mathbf{9}$ and 10) to the well-characterized zwitterionic, tris(phosphino)borate-iron-ethyl complex $\left(\mathrm{PhBP}_{3}\right) \mathrm{Fe}(\mathrm{Et})$ that was observed as an intermediate in ethylene hydrogenation with the previously reported iron $\left(\mathrm{PhBP}_{3}\right) \mathrm{Fe}$ system. ${ }^{3 \mathrm{e}}$

Complexes 1, $\mathbf{2}$, and $\mathbf{3}$ hydrogenate both phenylacetylene (1 equiv) and styrene (1 equiv) to ethylbenzene $\left(1 \mathrm{~atm} \mathrm{H}_{2}\right)$ with $\mathbf{3}$ as the observable iron-containing product. The in situ ${ }^{1} \mathrm{H}$ NMR spectrum of styrene hydrogenation reactions using $\mathbf{1}, \mathbf{2}$, or $\mathbf{3}$ show styrene, ethylbenzene and $\mathbf{3}$ in solution during the reaction course. Furthermore, for styrene hydrogenation with $\mathrm{D}_{2}$ the ${ }^{2} \mathrm{H}$ NMR spectrum and GC-MS data of the reaction mixture show incorporation of deuterium onto both olefinic carbon atoms of free styrene, indicating that styrene coordination to the iron-center and insertion/ $\beta$-hydride elimination processes are reversible.

Under stoichiometric conditions, the addition of 1 equiv of styrene to a solution of $\mathbf{2}$ in $d_{6}$ benzene and under $\mathrm{N}_{2}(1 \mathrm{~atm})$ cleanly generates 1 equiv of ethylbenzene and $\mathbf{1}$ (Scheme 6ii). In contrast, running the same reaction under a static vacuum yields a mixture of styrene, ethylbenzene, 1, and $\mathbf{2}$ (Scheme 6-iii). These observations suggest that excess $\mathrm{H}_{2}$ or $\mathrm{N}_{2}$ is required for the hydrogenations to proceed to completion. Moreover, the bridging monohydride appears competent for transfer to a substrate.

Substrates including trans-stilbene, N-benzylideneaniline, acetone, and acetophenone were not hydrogenated under similar conditions. Compounds $\mathbf{5}$ and $\mathbf{7}$ also do not hydrogenate ethylene, styrene, or phenylacetylene under the same conditions.

\section{Catalytic Hydrogenations}

Under the catalytic conditions of $0.01 \mathrm{M} 1,1 \mathrm{~atm}$ of $\mathrm{H}_{2}$, and 30 equiv of the substrate in $d_{6}$ benzene at room temperature, ethylene, styrene, and phenylacetylene are hydrogenated to ethane and ethylbenzene, respectively (Table 1). Compounds $\mathbf{2}$ and $\mathbf{3}$ can also be used as precatalysts. Ambient laboratory light does not affect the reaction and the catalysis is not inhibited by elemental mercury; it thus appears to be a homogeneous process. Norbornene is hydrogenated to norbornane, and with an atmosphere of $\mathrm{D}_{2}$ in place of $\mathrm{H}_{2}$ the cis-addition product exo,exo-2,3- $d_{2}$-norbornane ${ }^{23}$ is exclusively observed, indicating the syn-addition of hydrogen and arguing against radical processes.

The hydrogenation catalysis was monitored by ${ }^{1} \mathrm{H}$ NMR spectroscopy with ferrocene as an internal integration standard. As with stoichiometric ethylene hydrogenation, the in situ ${ }^{1} \mathrm{H}$ NMR spectra of the catalytic ethylene hydrogenation reaction indicate the presence of ethylene adduct $\mathbf{8}$ and the putative ethyl-borohydride intermediate $\mathbf{A}$ as the iron-containing species during the reaction course. Complex $\mathbf{3}$ is the iron-containing product at the completion of the reaction. For styrene hydrogenation, styrene, ethylbenzene, and $\mathbf{3}$ are observed during catalysis, and scrambling of deuterium into the vinylic positions of styrene is observed under $\mathrm{D}_{2}$. In contrast, for phenylacetylene hydrogenation complex $\mathbf{9}$ is the only observed iron-species early in the reaction when the phenylacetylene concentration is high. As phenylacetylene is consumed, styrene and $\mathbf{3}$ form, and ethylbenzene begins to develop slowly thereafter.

Attempting to increase the rate of catalysis by elevating the reaction temperature results in catalyst decomposition. The decomposition product (11) can be synthesized independently 
in near quantitative yields by heating $3\left(80^{\circ} \mathrm{C}\right)$ under $\mathrm{H}_{2}(1 \mathrm{~atm})$ for $2 \mathrm{~h}$. The XRD structure of $\mathbf{1 1}$ indicates that a $\mathrm{B}-\mathrm{C}_{\mathrm{Ar}}$ bond is cleaved from the TPB ligand fragment (Figure 5). This result offers the cautionary note that $\mathrm{B}-\mathrm{C}_{\mathrm{Ar}}$ bond cleavage to give metal-borohydride products is a viable catalyst decomposition pathway.

Based on the results from the stoichiometric and catalytic experiments, we propose a plausible mechanistic scenario to account for the observed catalytic styrene hydrogenation by 1 (Scheme 7A), and in doing so underscore interesting aspects of the mechanism that remain unanswered. Starting from precatalyst $\mathbf{1}$, addition of $\mathrm{H}_{2}$ generates $\mathbf{3}$, a species that can be observed by ${ }^{1} \mathrm{H}$ NMR spectroscopy during catalytic runs (resting state). Subsequent substitution of the apical $\mathrm{H}_{2}$ ligand for styrene forms the unobserved iron-styrene-hydrideborohydride species $\mathbf{B}$, and insertion into the terminal hydride affords the iron-alkyl intermediate $\mathbf{A}^{\prime}$. Intermediate $\mathbf{A}^{\prime}$ is analogous to the ethyl species $\mathbf{A}$ (Scheme 6-i), and is also related to the structurally characterized acetylide-borohydride complex $\mathbf{1 0}$ (Scheme 4). Olefin coordination and insertion appears to be reversible, as labeling studies show deuterium is exchanged into the vinylic positions of free styrene under a $\mathrm{D}_{2}$ atmosphere. Elimination of ethylbenzene in the presence of $\mathrm{H}_{2}$ regenerates the catalyst resting state.

The conversion of $\mathbf{1}$ to $\mathbf{3}$ likely proceeds via the $\mathrm{H}_{2}$-adduct intermediate $\mathbf{C}$ depicted in Scheme 7B by $\mathrm{H}_{2}$-for- $\mathrm{N}_{2}$ ligand exchange. While we have not detected such a species in the present (TPB)Fe system, its cobalt analogue (TPB) $\mathrm{Co}\left(\mathrm{H}_{2}\right)$ can be isolated and has been thoroughly characterized, ${ }^{24}$ as has the isoelectronic iron complex $\left[\left(\mathrm{SiP}^{\prime P r}{ }_{3}\right) \mathrm{Fe}\left(\mathrm{H}_{2}\right)\right]^{+.17} \mathrm{~N}_{2} /$ $\mathrm{H}_{2}$ exchange is facile in these well-defined Co and $\mathrm{Fe}$ systems, and by extension we infer it would also be facile for (TPB) $\mathrm{Fe}\left(\mathrm{N}_{2}\right) \mathbf{1}$ to afford (TPB) $\mathrm{Fe}\left(\mathrm{H}_{2}\right) \mathbf{C}$ before additional reactions ensue. Since $\mathrm{H}_{2}$ reacts with $\mathbf{1}$, but not with $\mathbf{5}$ and $\mathbf{7}$ at room temperature, we think that facile $\mathrm{H}_{2}$ substitution for $\mathrm{N}_{2}$ most likely occurs prior to $\mathrm{H}-\mathrm{H}$ bond cleavage. We appreciate that while this scenario is consistent with the data available, it is not demanded by the available data. For instance, it is alternatively possible that styrene substitution for the $\mathrm{N}_{2}$ ligand in $\mathbf{1}$ precedes $\mathrm{H}_{2}$ addition to form intermediate $\mathbf{B}$. No direct evidence rules out this possibility. We prefer suggesting that the $\mathrm{H}_{2}$ /dihydride species 3 precedes styrene binding because of the observation that $\mathrm{H}_{2}$ addition/activation by other (TPB)Fe(L) adducts, for example 4 and $\mathbf{6}$, is very slow, and also because $\mathrm{N}_{2}$, and presumably therefore also $\mathrm{H}_{2}$, displaces ethylene from $\mathbf{8}$ in solution (regenerating $\mathbf{1}$ or $(\mathrm{TPB}) \mathrm{Fe}\left(\mathrm{H}_{2}\right)$ ).

The final ethylbenzene elimination step can be envisioned to occur through two plausible routes (Scheme 7B). One such pathway involves a reductive elimination step where hydride transfer directly from the borohydride subunit generates the alkane product to form $\mathbf{3}$, likely via the dihydrogen adduct intermediate $\mathbf{C}$. The other pathway proceeds through alkane elimination by hydrogenolysis of the phenylethyl group without hydride transfer from the borohydride subunit.

While the available data do not firmly distinguish between the two product elimination pathways shown in Scheme 7B, the stoichiometric hydrogenation studies described above show that 1 equiv of styrene is completely hydrogenated to ethylbenzene by $\mathbf{2}$ under an $\mathrm{N}_{2}$ atm (Scheme 6-ii). This observation implies that $\mathbf{2}$ can serve as the source of the two H-atom equivalents delivered to styrene. From complex $\mathbf{2}$, substitution of the apical $\mathrm{N}_{2}$ ligand for styrene in $\mathbf{2}$ would generate the styrene adduct intermediate $\mathbf{B}$. Subsequent insertion of the bound styrene into the cis $\mathrm{Fe}-\mathrm{H}$ would afford intermediate $\mathbf{A}^{\prime}$, which in the absence of $\mathrm{H}_{2}$ at least, eliminates ethylbenzene concomitant with $\mathrm{N}_{2}$ binding to reform $\mathbf{1}$. The presence of exogenous $\mathrm{N}_{2}$ (or alternatively $\mathrm{H}_{2}$ ) facilitates the generation of ethylbenzene. As noted in Scheme 6-iii, the stoichiometric reaction under static vacuum between 2 and styrene is quite slow compared with the same reaction under $\mathrm{N}_{2}$ (Scheme 6-ii). This observation can be 
explained by presuming the conversion of intermediate $\mathbf{A}^{\prime}$ to $\mathbf{1}$ requires $\mathrm{N}_{2}$ association prior to elimination to generate ethylbenzene.

\section{CONCLUSIONS}

In summary, we have demonstrated that the Fe-B bond in ferraboratranes (TPB)Fe(L) (where $\mathrm{L}=\mathrm{N}_{2}, 1 ; \mathrm{CN}^{t} \mathrm{Bu}, 4 ; \mathrm{CO}, \mathbf{6}$ ) can facilitate heterolytic cleavage of $\mathrm{H}_{2}$ and of the $\mathrm{C}(\mathrm{sp})-\mathrm{H}$ and $\mathrm{C}\left(\mathrm{sp}^{2}\right)-\mathrm{H}$ bonds of arylacetylenes and formaldehyde, respectively, resulting in Fe-B bond rupture and formal hydride transfer to the boron of the ligand scaffold. The formal hydride transfer from the $\mathrm{C}(\mathrm{sp})-\mathrm{H}$ of arylacetylenes to give iron-acetylide complexes is distinct from traditional syntheses of metal-acetylide complexes in that a hydride equivalent is formally abstracted by the Lewis acidic borane unit in $\mathbf{1}$ from a $\mathrm{C}(\mathrm{sp})-\mathrm{H}$ hydrogen. ${ }^{25}$

Dihydrogen addition across the Fe-B bond is reversible, and the boron is also capable of shuttling the hydride equivalent derived from $\mathrm{H}_{2}$ to unsaturated substrates under stoichiometric hydrogenation conditions. The hydrogen chemistry of this (TPB)Fe(L) system contrasts with the related nickel ${ }^{26}$ and cobalt ${ }^{24}$ complexes of TPB, where the metalboron bond remains intact under an $\mathrm{H}_{2}$ atmosphere.

An understanding of the factors that govern metal-boron bond cleavage will aid in the development of cooperative catalytic reactions in metallaboratranes. The direct role, if any, of the borane ligand in assisting the $\mathrm{H}_{2}$ cleavage step is an interesting question in this context for the present iron and recently reported diphosphine-borane-iron systems, ${ }^{27}$ and also conceptually related to the nickel system (Scheme 1) ${ }^{10}$ Determining whether there is a cooperative interaction between the coordinated $\mathrm{H}_{2}$ ligand, the iron center, and the borane subunit en route to $\mathrm{H}-\mathrm{H}$ cleavage (and its microscopic reverse), akin to $\mathrm{H}-\mathrm{H}$ cleavage by frustrated Lewis pairs, ${ }^{9}$ calls for detailed theoretical studies that are the subject of ongoing research.

\section{EXPERIMENTAL}

\section{General Considerations}

All manipulations were carried out using standard glovebox or Schlenk techniques under an $\mathrm{N}_{2}$ atmosphere. Unless otherwise noted, solvents were deoxygenated and dried by thoroughly sparging with $\mathrm{N}_{2}$ gas followed by passage through an activated alumina column in the solvent purification system by SG Water, USA LLC. Deuterated solvents and $\mathrm{D}_{2}$ gas were purchased from Cambridge Isotope Laboratories, INC. The deuterated solvents were degassed and dried over activated $3 \AA$ sieves prior to use. Unless otherwise noted, all compounds were purchased commercially and used without further purification. TPB, ${ }^{13}$ $\left(\mathrm{SiP}^{\mathrm{PPr}}{ }_{3}\right) \mathrm{Fe}(\mathrm{Me}),{ }^{19}\left(\mathrm{SiP}^{\mathrm{PPr}}{ }_{3}\right) \mathrm{Fe}\left(\mathrm{N}_{2}\right)(\mathrm{H}),{ }^{17}$ and monodeuterated phenyl- and tolylacetylene $\left(\mathrm{PhC}_{2} \mathrm{D} \text { and } \mathrm{TolC}_{2} \mathrm{D}\right)^{28}$ were synthesized by literature procedures. Elemental analyses were performed by Midwest Microlab, LLC., Indianapolis, IN.

NMR spectra were recorded on Varian $300 \mathrm{MHz}, 400 \mathrm{MHz}$, and $500 \mathrm{MHz}$ spectrometers. ${ }^{1} \mathrm{H}$ and ${ }^{13} \mathrm{C}$ chemical shifts are reported in ppm relative to residual solvent as internal standards. ${ }^{31} \mathrm{P}$ and ${ }^{11} \mathrm{~B}$ chemical shifts are reported in ppm relative to $85 \%$ aqueous $\mathrm{H}_{3} \mathrm{PO}_{4}$ and $\mathrm{BF}_{3} \cdot \mathrm{Et}_{2} \mathrm{O}$, respectively. Multiplicities are indicated by br (broad), $\mathrm{s}$ (singlet), $\mathrm{d}$ (doublet), $\mathrm{t}$ (triplet), quart (quart), quin (quintet), multiplet (m), d-d (doublet-of-doublets), and t-d (triplet-of-doublets).

FT-IR measurements were obtained on samples prepared as $\mathrm{KBr}$ pellets or in solution using a Bio-Rad Excalibur FTS 300 spectrometer with Varian Resolutions Pro software at $4 \mathrm{~cm}^{-1}$ 
resolution. The ATR-IR measurements were measured on a thin film of the complex obtained from evaporating a drop of the solution on the surface of a Bruker APLHA ATRIR Spectrometer probe (Platinum Sampling Module, diamond, OPUS software package) at 2 $\mathrm{cm}^{-1}$ resolution. IR intensities indicated by s (strong), $\mathrm{m}$ (medium), and w (weak).

\section{X-ray Crystallography}

X-ray diffraction was measured on the Bruker Kappa Apex II diffractometer with Mo Ka radiation. Structures were solved using the SHELXS software and refined against $\mathrm{F}^{2}$ on all data sets by full matrix least squares with SHELXL. The crystals were mounted on a glass fiber with Paratone oil.

\section{Computational Methods}

Geometry optimizations were performed using the Gaussian03 package. B3LYP exchangecorrelation functional was employed with a 6-31G(d) basis set. The GDIIS algorithm was used. A full frequency calculation was performed on each structure to ensure that they were the true minima. A single negative vibrational frequency was observed for the transition state between $\mathbf{3}$ and its equatorial- $\mathrm{H}_{2}$ isomer, confirming that this structure was the transition state. See SI for full a description of the computational method.

\section{HD Gas Generation}

$\mathrm{D}_{2} \mathrm{O}(1 \mathrm{~mL})$ was added to an evacuated, cooled sample $\left(-78^{\circ} \mathrm{C}\right)$ of solid lithium aluminum hydride (316 mg, $8.2 \mathrm{mmol}$ ) in a Schlenk flask. An evacuated Schlenk line was filled with the resulting HD gas (ca. $1 \mathrm{~atm})$ as the Schlenk flask was warmed to room temperature. A JYoung NMR tube containing a freeze-pump-thawed solution was the respective complex was exposed to the HD gas.

Synthesis of (TPB) $(\boldsymbol{\mu}-\mathrm{H}) \mathrm{Fe}\left(\mathbf{N}_{\mathbf{2}}\right)(\mathbf{H})(\mathbf{2})$-A J-Young NMR tube containing a brown-red solution 1 ( $20.3 \mathrm{mg}, 31.1 \mathrm{mmol})$ in $\mathrm{C}_{6} \mathrm{H}_{6}(0.8 \mathrm{~mL})$ was freeze-pump-thawed (3x) and, with the J-Young tube frozen with liquid nitrogen, exposed to $\mathrm{H}_{2}$ (1.2 equiv). The solution was thawed and mixed, giving a yellow solution. An atmosphere of $\mathrm{N}_{2}$ was subsequently introduced and the reaction was mixed for $2 \mathrm{~h}$ to yield $\mathbf{2}\left(100 \%\right.$ yield by ${ }^{1} \mathrm{H}$ NMR spectroscopy with a ferrocene integration standard). Alternatively, 2 could be synthesized from 3 by degassing a solution of $\mathbf{3}$ of free $\mathrm{H}_{2}$ by freeze-pump-thaw (3x), exposing it to an $\mathrm{N}_{2}$ atmosphere, and mixing the solution overnight (100\% yield by ${ }^{1} \mathrm{H}$ NMR spectroscopy with a ferrocene integration standard). Yields could not be determined by mass because 2 was unstable to prolonged exposure to dynamic vacuum. Yellow-orange XRD quality crystals were grown in a concentrated solution of pentane:THF (10:1) at $-30{ }^{\circ} \mathrm{C} .{ }^{1} \mathrm{H}$ NMR $\left(\mathrm{C}_{6} \mathrm{D}_{6}, 300 \mathrm{MHz}\right): \delta 7.9\left(2 \mathrm{H}, \mathrm{d},{ }^{3} J_{\mathrm{H}-\mathrm{H}}=6 \mathrm{~Hz}, \mathrm{Ar}-H\right), \delta 7.7(1 \mathrm{H}, \mathrm{br} \mathrm{s}, \mathrm{Ar}-H), \delta 7.3(3 \mathrm{H}$, $\left.\mathrm{d},{ }^{3} J_{\mathrm{H}-\mathrm{H}}=6 \mathrm{~Hz}, \mathrm{Ar}-H\right), \delta 7.0\left(3 \mathrm{H}, \mathrm{t},{ }^{3} J_{\mathrm{H}-\mathrm{H}}=9 \mathrm{~Hz}, \mathrm{Ar}-H\right), \delta 2.7\left(4 \mathrm{H}, \mathrm{d},{ }^{2} J_{\mathrm{P}-\mathrm{H}}=18 \mathrm{~Hz}\right.$, $\mathrm{PCH}), \delta 2.4(2 \mathrm{H}, \mathrm{br} \mathrm{s}, \mathrm{PCH}), \delta 1.4\left(6 \mathrm{H}, \mathrm{d},{ }^{3} J_{\mathrm{H}-\mathrm{H}}=6 \mathrm{~Hz}, \mathrm{CH}\right)_{3}, \delta 1.3\left(12 \mathrm{H}, \mathrm{br} \mathrm{s}, \mathrm{CH}_{3}\right), \delta 1.1$ $\left(6 \mathrm{H}, \mathrm{d}-\mathrm{d},{ }^{3} J_{\mathrm{P}-\mathrm{H}}=15 \mathrm{~Hz},{ }^{3} \mathrm{~J}_{\mathrm{H}-\mathrm{H}}=6 \mathrm{~Hz}, \mathrm{CH}_{3}\right), \delta 0.8\left(6 \mathrm{H}, \mathrm{d},{ }^{3} J_{\mathrm{P}-\mathrm{H}}=9 \mathrm{~Hz}, \mathrm{CH}_{3}\right), \delta-9.6(1 \mathrm{H}$, $\left.\mathrm{d}-\mathrm{t},{ }^{2} J_{\mathrm{H}-\mathrm{P} c i s}=81 \mathrm{~Hz},{ }^{2} J_{\mathrm{H}-\mathrm{P} \text { trans }}=36 \mathrm{~Hz}, \mathrm{Fe}-H\right), \delta-30.4(1 \mathrm{H}, \mathrm{s}, \mathrm{Fe}-(\mu-H)-\mathrm{B}) .{ }^{2} \mathrm{H}$ NMR $\left(\mathrm{C}_{6} \mathrm{H}_{6} / \mathrm{C}_{6} \mathrm{D}_{6}, 76 \mathrm{MHz}\right): \delta-9.5$ (1D, br s), $\delta-30.3$ (1D, br s). ${ }^{31} \mathrm{P}$ NMR $\left(\mathrm{C}_{6} \mathrm{D}_{6}, 121 \mathrm{MHz}\right): \delta$ $73.6(2 \mathrm{P}, \mathrm{s}), \delta 64.2(1 \mathrm{P}, \mathrm{s}) .{ }^{13} \mathrm{C} \mathrm{NMR}\left(\mathrm{C}_{6} \mathrm{D}_{6}, 125 \mathrm{MHz}\right): \delta 161.9\left(\mathrm{~s}, C^{\mathrm{Ar}}\right), \delta 143.5\left(\mathrm{~s}, C^{\mathrm{Ar}}\right), \delta$ $141.0\left(\mathrm{~s}, C^{\mathrm{Ar}}\right), \delta 132.3\left(\mathrm{~s}, C^{\mathrm{Ar}}\right), \delta 131.8\left(\mathrm{~s}, C^{\mathrm{Ar}}\right), \delta 131.3\left(\mathrm{~s}, C^{\mathrm{Ar}}\right), \delta 130.3\left(\mathrm{~s}, C^{\mathrm{Ar}}\right), \delta 124.6$ (s, $\left.C^{\mathrm{Ar}}\right), \delta 124.0\left(\mathrm{~s}, C^{\mathrm{Ar}}\right), \delta 32.0(\mathrm{~s}, \mathrm{PCH}), \delta 29.4(\mathrm{~s}, \mathrm{PCH}), \delta 28.5(\mathrm{~s}, \mathrm{PCH}), \delta 22.8\left(\mathrm{~s}, C_{3}\right)$, $\delta 20.1\left(\mathrm{~s}, \mathrm{CH}_{3}\right), \delta 19.7\left(\mathrm{~s}, \mathrm{CH}_{3}\right), \delta 18.9\left(\mathrm{~s}, \mathrm{CH}_{3}\right) .{ }^{11} \mathrm{~B} \mathrm{NMR}\left(\mathrm{C}_{6} \mathrm{D}_{6}, 128 \mathrm{MHz}\right): \delta 8.2(\mathrm{br})$. IR $\left(\mathrm{KBr}, \mathrm{cm}^{-1}\right): 2071$ (s, N=N), 1960 (w) 1934 (w). UV-vis (THF, $\left.\mathrm{nm}\left\{\mathrm{M}^{-1} \mathrm{~cm}^{-1}\right\}\right): 328$ \{shoulder, 500\}, 280 \{shoulder, 11250\}. Anal.: Elemental analysis could not be obtained because of the instability of the compound under dynamic vacuum. 
Synthesis of (TPB) $(\boldsymbol{\mu}-\mathrm{H}) \mathrm{Fe}\left(\mathrm{H}_{\mathbf{2}}\right)(\mathrm{H})(\mathbf{3})$-A J-Young NMR tube containing a brown-red solution 1 (21 mg, $31.1 \mathrm{mmol})$ in $\mathrm{C}_{6} \mathrm{H}_{6}(0.8 \mathrm{~mL})$ was freeze-pump-thawed (3x). Upon warming to room temperature, the sample was exposed to $\mathrm{H}_{2}(1 \mathrm{~atm})$, resulting in a clear yellow solution. The reaction was mixed for $24 \mathrm{~h}$ to give 3 (100\% by ${ }^{1} \mathrm{H}$ NMR spectroscopy with a ferrocene integration standard). The yield could not be determined by weight because 3 was unstable to prolonged exposure to dynamic vacuum. Yellow-orange XRD quality crystals were grown under $1 \mathrm{~atm}$ of $\mathrm{H}_{2}$ in a concentrated solution of pentane:THF (10:1) at $-78{ }^{\circ} \mathrm{C} .{ }^{1} \mathrm{H}$ NMR $\left(\mathrm{C}_{6} \mathrm{D}_{6}, 300 \mathrm{MHz}\right): \delta 8.0\left(3 \mathrm{H}, \mathrm{d},{ }^{3} J_{\mathrm{H}-\mathrm{H}}=6 \mathrm{~Hz}, \mathrm{Ar}-H\right), \delta 7.3\left(3 \mathrm{H}, \mathrm{t},{ }^{3} J_{\mathrm{H}-\mathrm{H}}=\right.$ $9 \mathrm{~Hz}, \operatorname{Ar}-H), \delta 7.2\left(3 \mathrm{H}, \mathrm{t},{ }^{3} J_{\mathrm{H}-\mathrm{H}}=9 \mathrm{~Hz}, \operatorname{Ar}-H\right), \delta 7.0\left(3 \mathrm{H}, \mathrm{d},{ }^{3} J_{\mathrm{H}-\mathrm{H}}=6 \mathrm{~Hz}, \mathrm{Ar}-H\right), \delta 4.47(\mathrm{~s}$, free $\left.\mathrm{H}_{2}\right), \delta 2.3(6 \mathrm{H}, \mathrm{m}, \mathrm{PC} H), \delta 1.0\left(18 \mathrm{H}, \mathrm{d}-\mathrm{d},{ }^{3} J_{\mathrm{H}-\mathrm{P}}=15 \mathrm{~Hz},{ }^{3} J_{\mathrm{H}-\mathrm{H}}=6 \mathrm{~Hz}, \mathrm{CH}_{3}\right), \delta 0.8$ $\left(18 \mathrm{H}, \mathrm{d}-\mathrm{d},{ }^{3} J_{\mathrm{H}-\mathrm{P}}=15 \mathrm{~Hz},{ }^{3} J_{\mathrm{H}-\mathrm{H}}=6 \mathrm{~Hz}, \mathrm{C} H_{3}\right), \delta-15.1(\mathrm{br} \mathrm{s}, 2 \mathrm{H}) . \mathrm{T}_{1 \text { min }}\left(d_{8}\right.$-toluene): $35 \mathrm{~ms}$ $\left(\delta-15.1,-32{ }^{\circ} \mathrm{C}\right) .{ }^{2} \mathrm{H}$ NMR $\left(\mathrm{C}_{6} \mathrm{H}_{6} / \mathrm{C}_{6} \mathrm{D}_{6}, 76 \mathrm{MHz}\right): \delta-15.4(1 \mathrm{D}, \mathrm{br} \mathrm{s}) .{ }^{31} \mathrm{P}$ NMR $\left(\mathrm{C}_{6} \mathrm{D}_{6}\right.$, $121 \mathrm{MHz}): \delta 90.0(3 \mathrm{P}, \mathrm{s}) .{ }^{13} \mathrm{C}$ NMR $\left(\mathrm{C}_{6} \mathrm{D}_{6}, 125 \mathrm{MHz}\right): \delta 163.5\left(\mathrm{~s}, C^{\mathrm{Ar}}\right), \delta 144.6\left(\mathrm{~s}, C^{\mathrm{Ar}}\right), \delta$ $144.1\left(\mathrm{~s}, C^{\mathrm{Ar}}\right), \delta 130.9\left(\mathrm{~d}, J_{\mathrm{P}-\mathrm{C}}=23 \mathrm{~Hz}, C^{\mathrm{Ar}}\right), \delta 124.5\left(\mathrm{~s}, C^{\mathrm{Ar}}\right), \delta 123.9\left(\mathrm{~s}, C^{\mathrm{Ar}}\right), \delta 28.6(\mathrm{~s}$, $\mathrm{PCH}), \delta 21.2\left(\mathrm{~s}, \mathrm{CH}_{3}\right), \delta 19.9\left(\mathrm{~s}, C_{3}\right) .{ }^{11} \mathrm{~B} \mathrm{NMR}\left(\mathrm{C}_{6} \mathrm{D}_{6}, 128 \mathrm{MHz}\right): \delta 7.5(\mathrm{br}) . \mathrm{IR}(\mathrm{KBr}$, $\mathrm{cm}^{-1}$ ): $2278(\mathrm{w}), 19618(\mathrm{w}), 1845$ (w). UV-vis (THF, nm $\left.\left\{\mathrm{M}^{-1} \mathrm{~cm}^{-1}\right\}\right): 377$ \{ shoulder, $1532\}, 275$ \{14532\}. Anal.: Elemental analysis could not be obtained because of the instability of the compound under dynamic vacuum.

Synthesis of (TPB)Fe(CN $\left.{ }^{t} \mathrm{Bu}\right)$ (4)-Tert-butyl isocyanide (20 mg, $\left.0.24 \mathrm{mmol}\right)$ was added to a brown solution of (TPB)Fe( $\left.\mathrm{N}_{2}\right)(40 \mathrm{mg}, 59 \mu \mathrm{mol})$ in benzene $(2 \mathrm{~mL})$, causing an instantaneous darkening upon gentle shaking. The volatiles were removed by lyophilization and the residue was extracted with tetramethylsilane $(2 \mathrm{~mL})$. The resulting dark brown solution was slowly concentrated down to $c a .0 .2 \mathrm{~mL}$ by vapor diffusion into hexamethyldisiloxane. Removal of the mother liquor by decantation, washing with cold tetramethylsilane $(2 \times 0.1 \mathrm{~mL})$ and drying in vacuo afforded $(\mathrm{TPB}) \mathrm{Fe}\left(\mathrm{CN}^{t} \mathrm{Bu}\right)$ as brown crystals (33 mg, 77\%). ${ }^{1} \mathrm{H}$ NMR $\left(\mathrm{C}_{6} \mathrm{D}_{6}, 300 \mathrm{MHz}\right): \delta 11.2(3 \mathrm{H}), \delta 9.2(3 \mathrm{H}), \delta 8.6(3 \mathrm{H}), \delta$ $8.5(9 \mathrm{H}), \delta 6.4(3 \mathrm{H}), \delta 5.2(9 \mathrm{H}), \delta 3.7(12 \mathrm{H}), \delta 2.9(9 \mathrm{H}), \delta-1.5(9 \mathrm{H}), \delta-2.3(3 \mathrm{H}) . \mathrm{IR}(\mathrm{KBr}$, $\left.\mathrm{cm}^{-1}\right)$ : $1972(\mathrm{C} \equiv \mathrm{N})$. UV-Vis (THF, $\left.\mathrm{nm}\left\{\mathrm{cm}^{-1} \mathrm{M}^{-1}\right\}\right): 600$ \{shoulder, 428$\}, 910\{70\} . \mu_{\text {eff }}$ $\left(\mathrm{C}_{6} \mathrm{D}_{6}\right.$, method of Evans, $\left.20^{\circ} \mathrm{C}\right): 1.7 \mu_{\mathrm{B}}$. Anal.: Calc'd for $\mathrm{C}_{41} \mathrm{H}_{64} \mathrm{BFeNP}_{3}$ : C 67.50, $\mathrm{H}$ 8.70, N 1.92; found: C 67.20, H 8.54, N 1.72.

Synthesis of $(\mathrm{TPB})(\boldsymbol{\mu}-\mathrm{H}) \mathrm{Fe}\left(\mathrm{CN}^{t} \mathrm{Bu}\right)(\mathrm{H})(5)$-A heavy-walled Schlenk tube containing a yellow-brown solution of $4(16.4 \mathrm{mg}, 22.4 \mathrm{mmol})$ in $\mathrm{C}_{6} \mathrm{H}_{6}(10 \mathrm{~mL})$ was freeze-pumpthawed (3x). Upon warming to room temperature, the sample was exposed to $\mathrm{H}_{2}(1 \mathrm{~atm})$ for a few minutes. The Schlenk tube was sealed and heated under vigorous mixing at $40{ }^{\circ} \mathrm{C}$ for $85 \mathrm{~h}$. Removal of the solvent in vacuo, extraction with $\mathrm{C}_{6} \mathrm{H}_{6}$, and lyophilization yielded a solid of $5(17.3 \mathrm{mg}, 98 \%)$. Room temperature evaporation of a solution of $\mathbf{5}$ in a diethyl ether:pentane ( $2 \mathrm{~mL}$ to $1 \mathrm{~mL}$ ) mixture yielded yellow crystals suitable for XRD analysis. ${ }^{1} \mathrm{H}$ NMR $\left(\mathrm{C}_{6} \mathrm{D}_{6}, 300 \mathrm{MHz}\right): \delta 8.1\left(1 \mathrm{H}, \mathrm{d},{ }^{3} J_{\mathrm{H}-\mathrm{H}}=9 \mathrm{~Hz}, \mathrm{Ar}-H\right), \delta 7.4\left(3 \mathrm{H}, \mathrm{d},{ }^{3} J_{\mathrm{H}-\mathrm{H}}=9 \mathrm{~Hz}, \mathrm{Ar}-\right.$ $H), \delta 7.2\left(3 \mathrm{H}, \mathrm{d},{ }^{3} \mathrm{~J}_{\mathrm{H}-\mathrm{H}}=6 \mathrm{~Hz}, \mathrm{Ar}-H\right), \delta 7.1\left(3 \mathrm{H}, \mathrm{d},{ }^{3} J_{\mathrm{H}-\mathrm{H}}=9 \mathrm{~Hz}, \mathrm{Ar}-H\right), \delta 2.7(2 \mathrm{H}, \mathrm{br} \mathrm{s}$, $\mathrm{PC} H), \delta 2.5(2 \mathrm{H}, \mathrm{br} \mathrm{s}, \mathrm{PC} H), \delta 2.2\left(2 \mathrm{H}, \mathrm{t},{ }^{2} J_{\mathrm{H}-\mathrm{P}}=9 \mathrm{~Hz}, \mathrm{PC} H\right), \delta 1.3\left(16 \mathrm{H}, \mathrm{m}, \mathrm{C} H_{3}\right), \delta 1.1$ $\left(9 \mathrm{H}, \mathrm{s}, \mathrm{C}\left(\mathrm{CH}_{3}\right)_{3}\right), \delta 1.0\left(6 \mathrm{H}, \mathrm{d},{ }^{3} J_{\mathrm{H}-\mathrm{H}}=6 \mathrm{~Hz}, \mathrm{CH}\right), \delta 0.8\left(6 \mathrm{H}, \mathrm{d}-\mathrm{d},{ }^{3} J_{\mathrm{H}-\mathrm{P}}=15 \mathrm{~Hz},{ }^{3} J_{\mathrm{H}-\mathrm{H}}=6\right.$ $\left.\mathrm{Hz}, \mathrm{CH}_{3}\right), \delta 0.7\left(6 \mathrm{H}, \mathrm{br} \mathrm{s}, \mathrm{CH}_{3}\right), \delta-11.7\left(1 \mathrm{H}, \mathrm{t}-\mathrm{d},{ }^{2} J_{\mathrm{H}-\mathrm{P} c i s}=87 \mathrm{~Hz},{ }^{2} J_{\mathrm{H}-\mathrm{P} t r a n s}=27 \mathrm{~Hz}, \mathrm{Fe}-\right.$ $H), \delta-23.9(1 \mathrm{H}$, br s, Fe- $(\mu-H)-\mathrm{B}) .{ }^{13} \mathrm{C}$ NMR $\left(\mathrm{C}_{6} \mathrm{D}_{6}, 125 \mathrm{MHz}\right): \delta 176.9$ (quart, ${ }^{2} J_{\mathrm{C}-\mathrm{P}}=8$ $\left.\mathrm{Hz}, C_{\mathrm{N}} \mathrm{Bu}\right), \delta 163.5\left(\mathrm{br} \mathrm{s}, C^{\mathrm{Ar}}\right), \delta 163.0\left(\mathrm{br} \mathrm{s}, C^{\mathrm{Ar}}\right), \delta 144.9\left(\mathrm{~m}, C^{\mathrm{Ar}}\right), \delta 143.0\left(\mathrm{~d}, J_{\mathrm{C}-\mathrm{P}}=20\right.$ $\left.\mathrm{Hz}, C^{\mathrm{Ar}}\right), \delta 131.9\left(\mathrm{~d},{ }^{2} J_{\mathrm{C}-\mathrm{P}}=7.5 \mathrm{~Hz}, C^{\mathrm{Ar}}\right), \delta 130.6\left(\mathrm{~d}, J_{\mathrm{C}-\mathrm{P}}=3.2 \mathrm{H}, C^{\mathrm{Ar}}\right), \delta 130.5\left(\mathrm{~d}, J_{\mathrm{C}-\mathrm{P}}=\right.$ $\left.2.5 \mathrm{H}, C^{\mathrm{Ar}}\right), \delta 128.6\left(\mathrm{~s}, C^{\mathrm{Ar}}\right), \delta 127.5\left(\mathrm{~s}, C^{\mathrm{Ar}}\right), \delta 124.2\left(\mathrm{~s}, C^{\mathrm{Ar}}\right), \delta 123.6\left(\mathrm{~s}, C^{\mathrm{Ar}}\right), \delta 55.3(\mathrm{~s}$, $\left.C\left(\mathrm{CH}_{3}\right)_{3}\right), \delta 31.6(\mathrm{~s}, \mathrm{PCH}), \delta 30.9(\mathrm{~s}, \mathrm{PCH}), \delta 29.2(\mathrm{~m}, \mathrm{PCH}), \delta 28.5\left(\mathrm{~d},{ }^{2} J_{\mathrm{C}-\mathrm{P}}=7.5 \mathrm{~Hz}\right.$, $\mathrm{PCH}), \delta 23.8\left(\mathrm{~s}, \mathrm{CH}_{3}\right), \delta 20.4\left(\mathrm{~s}, \mathrm{CH}_{3}\right), \delta 20.3\left(\mathrm{~m}, \mathrm{CH}_{3}\right), \delta 20.2\left(\mathrm{~s}, \mathrm{CH}_{3}\right), \delta 19.9\left(\mathrm{~s}, \mathrm{CH}_{3}\right), \delta$ $19.7\left(\mathrm{~s}, \mathrm{CH}_{3}\right) .{ }^{31} \mathrm{P}$ NMR $\left(\mathrm{C}_{6} \mathrm{D}_{6}, 121 \mathrm{MHz}\right): \delta 81.3\left(2 \mathrm{P}, \mathrm{d},{ }^{2} J_{\mathrm{P}-\mathrm{P}}=63 \mathrm{~Hz}\right), \delta 72.4(1 \mathrm{P}, \mathrm{s}) . \mathrm{IR}$ $\left(\mathrm{KBr}, \mathrm{cm}^{-1}\right): 2027(\mathrm{~s}, \mathrm{C} \equiv \mathrm{N}), 1942(\mathrm{w}, \mathrm{Fe}-\mathrm{H}) . \mathrm{UV}-\mathrm{Vis}\left(\mathrm{THF}, \mathrm{nm}\left\{\mathrm{cm}^{-1} \mathrm{M}^{-1}\right\}\right): 205\{5530\}$, 
$224\{15437\}, 245\{17142\}, 255\{16635\}, 285\{4117\}, 335$ \{shoulder, 2166$\}, 400\{1830\}$. Anal: Calc'd for $\mathrm{C}_{41} \mathrm{H}_{66} \mathrm{BFeNP}_{3}$ : C 67.32, H 8.96, N 1.91; found: C 66.59, H 8.61, N 1.30.

Synthesis of (TPB) $(\boldsymbol{\mu}-\mathrm{H}) \mathrm{Fe}(\mathrm{CO})(\mathrm{H})(\mathbf{7})$ from $\mathbf{6}$ and $\mathrm{H}_{2}$-In a J-Young NMR tube, 6 $(6.0 \mathrm{mg}, 8.9 \mu \mathrm{mol})$ was dissolved in $\mathrm{C}_{6} \mathrm{H}_{6}(0.7 \mathrm{~mL})$ to give a brown-red solution. The solution was freeze-pump-thawed ( $3 \mathrm{x}$ ) and subsequently exposed to $\mathrm{H}_{2}(1 \mathrm{~atm})$ for $c a .5$ $\mathrm{min}$. The reaction was then heated at $80^{\circ} \mathrm{C}$ for 5 days, during which time a clear yellow solution developed. Removal of the solvent in vacuo, extraction with $\mathrm{C}_{6} \mathrm{H}_{6}$, and lyophilization yielded a yellow solid of $7(5.9 \mathrm{mg}, 98 \%)$. Room temperature evaporation of a solution of 7 in a diethyl ether:pentane ( $1 \mathrm{~mL}$ to $0.5 \mathrm{~mL})$ mixture yielded yellow analytically pure 7. ${ }^{1} \mathrm{H}$ NMR $\left(\mathrm{C}_{6} \mathrm{D}_{6}, 300 \mathrm{MHz}\right): \delta 8.1\left(2 \mathrm{H}, \mathrm{d},{ }^{3} J_{\mathrm{H}-\mathrm{H}}=6 \mathrm{~Hz}, \mathrm{Ar}-H\right), \delta 7.9$ $\left(1 \mathrm{H}, \mathrm{d},{ }^{2} J_{\mathrm{P}-\mathrm{H}}=9 \mathrm{~Hz}, \mathrm{Ar}-H\right), \delta 7.2(4 \mathrm{H}, \mathrm{m}, \mathrm{Ar}-H), \delta 7.0(4 \mathrm{H}, \mathrm{m}, \mathrm{Ar}-H), \delta 2.6\left(2 \mathrm{H}, \mathrm{t},{ }^{2} J_{\mathrm{H}-\mathrm{P}}=\right.$ $3 \mathrm{~Hz}, \mathrm{PC} H), \delta 2.4\left(2 \mathrm{H}, \mathrm{q},{ }^{2} J_{\mathrm{H}-\mathrm{P}}=6 \mathrm{~Hz}, \mathrm{PC} H\right), \delta 2.2\left(2 \mathrm{H}, \mathrm{t},{ }^{2} J_{\mathrm{H}-\mathrm{P}}=6 \mathrm{~Hz}, \mathrm{PC} H\right), \delta 1.4(6 \mathrm{H}$, $\left.\mathrm{d},{ }^{3} J_{\mathrm{H}-\mathrm{P}}=6 \mathrm{~Hz}, \mathrm{CH}_{3}\right), \delta 1.2\left(12 \mathrm{H}, \mathrm{m}, \mathrm{C} H_{3}\right), \delta 0.9\left(6 \mathrm{H}, \mathrm{d},{ }^{3} J_{\mathrm{H}-\mathrm{P}}=6 \mathrm{~Hz}, \mathrm{CH}\right), \delta 0.8(6 \mathrm{H}, \mathrm{d}-$ $\left.\mathrm{d},{ }^{3} J_{\mathrm{H}-\mathrm{P}}=8 \mathrm{~Hz},{ }^{3} J_{\mathrm{H}-\mathrm{H}}=6 \mathrm{~Hz}, \mathrm{CH}_{3}\right), \delta 0.6\left(6 \mathrm{H}, \mathrm{d},{ }^{3} J_{\mathrm{H}-\mathrm{P}}=6 \mathrm{~Hz}, \mathrm{CH}\right) . \delta-11.6(1 \mathrm{H}, \mathrm{t}-$ d, $\left.{ }^{2} J_{\mathrm{H}-\mathrm{P} c i s}=81 \mathrm{~Hz},{ }^{2} J_{\mathrm{H}-\mathrm{P} \text { trans }}=21 \mathrm{~Hz}, \mathrm{Fe}-H\right), \delta-20.0(1 \mathrm{H}, \mathrm{br} \mathrm{s}, \mathrm{Fe}-(\mu-H)-\mathrm{B}) .{ }^{2} \mathrm{H}$ NMR $\left(\mathrm{C}_{6} \mathrm{H}_{6}, 76 \mathrm{~Hz}\right): \delta-12.3\left(1 \mathrm{D}, \mathrm{t},{ }^{2} \mathrm{JP}_{\mathrm{P}-\mathrm{D}}=10 \mathrm{~Hz}\right), \delta-20.8(1 \mathrm{D}, \mathrm{br} \mathrm{s}) .{ }^{13} \mathrm{C}$ NMR (THF with 1 drop of $\mathrm{C}_{6} \mathrm{D}_{6}, 125 \mathrm{MHz}$ ): $\delta 222.7$ (br s, CO), $\delta 161.8$ (br s, $C^{\mathrm{Ar}}$ ), $\delta 142.9$ (br s, ${ }^{1} J_{\mathrm{C}-\mathrm{P}}=19$ $\left.\mathrm{Hz}, C^{\mathrm{Ar}}\right), \delta 140.8\left(\mathrm{br} \mathrm{s},{ }^{2} J_{\mathrm{C}-\mathrm{P}}=16 \mathrm{~Hz}, C^{\mathrm{Ar}}\right), \delta 131.0\left(\mathrm{~s}, C^{\mathrm{Ar}}\right), \delta 129.8\left(\mathrm{~s}, C^{\mathrm{Ar}}\right), \delta 128.5(\mathrm{~s}$, $\left.C^{\mathrm{Ar}}\right), \delta 128.0\left(\mathrm{~s}, C^{\mathrm{Ar}}\right), \delta 124.0\left(\mathrm{~s}, C^{\mathrm{Ar}}\right), \delta 123.4\left(\mathrm{~s}, C^{\mathrm{Ar}}\right), \delta 30.8(\mathrm{~s}, \mathrm{PCH}), \delta 28.3(\mathrm{~s}, \mathrm{P} C \mathrm{H}), \delta$ $27.7(\mathrm{~s}, \mathrm{PCH}), \delta 22.3\left(\mathrm{~s}, \mathrm{CH}_{3}\right), \delta 19.1\left(\mathrm{~s}, \mathrm{CH}_{3}\right), \delta 18.8\left(\mathrm{~s}, \mathrm{CH}_{3}\right), \delta 18.1\left(\mathrm{~s}, \mathrm{CH}_{3}\right) .{ }^{31} \mathrm{P} \mathrm{NMR}$ $\left(\mathrm{C}_{6} \mathrm{D}_{6}, 121 \mathrm{MHz}\right): \delta 83.4\left(2 \mathrm{P}, \mathrm{d},{ }^{2} \mathrm{~J}_{\mathrm{P}-\mathrm{H}}=21 \mathrm{~Hz}\right), \delta 72.8(1 \mathrm{P}, \mathrm{s}) . \mathrm{IR}\left(\mathrm{KBr}, \mathrm{cm}^{-1}\right): 1898(\mathrm{~s}$, $\mathrm{C} \equiv \mathrm{O}), 1967$ (w, Fe-H). UV-Vis (THF, nm $\left.\left\{\mathrm{cm}^{-1} \mathrm{M}^{-1}\right\}\right): 270\{4333\}, 280\{4111\}, 390$ $\{1400\}$. Anal.: Calc'd for $\mathrm{C}_{37} \mathrm{H}_{56} \mathrm{BFeOP}_{3}$ : C 65.70, $\mathrm{H}$ 8.34; found: $\mathrm{C} 65.64, \mathrm{H}$ 8.08.

Synthesis of (TPB)( $\mu-\mathrm{H}) \mathrm{Fe}(\mathrm{CO})(\mathrm{H})(\mathbf{7})$ from Formaldehyde-Compound $\mathbf{1}(8 \mathrm{mg}$, $11.8 \mu \mathrm{mol})$ or $2(6 \mathrm{mg}, 8.9 \mu \mathrm{mol})$ was mixed with excess paraformaldehyde in $\mathrm{C}_{6} \mathrm{H}_{6}$ for $3 \mathrm{~h}$ to give a turbid, light yellow solution. The excess paraformaldehyde was filtered away and the solution was pumped down to give 7 as a yellow solid (from 1, $8 \mathrm{mg}, 100 \%$; from 2, 7 $\mathrm{mg}, 100 \%)$. Spectroscopic data is identical to those listed above.

Synthesis of (TPB)Fe( $\left.\mathrm{C}_{2} \mathrm{H}_{4}\right)(8)$-A J-Young NMR tube containing an orange solution of $\mathbf{3}(8.4 \mathrm{mg}, 12.5 \mu \mathrm{mol})$ in $\mathrm{C}_{6} \mathrm{H}_{6}(0.8 \mathrm{~mL})$ was freeze-pump-thawed ( $\left.3 \mathrm{x}\right)$ and exposed to ethylene gas $(1 \mathrm{~atm})$ for $c a .1$ minute. Mixing immediately gave a brown solution of $\mathbf{8}$. Removal of solvent in vacuo yielded a brown solid ( $8.3 \mathrm{mg}$, 99\%) of $\mathbf{8}$. Dissolution of this solid under $\mathrm{N}_{2}$ atmosphere gave mostly $\mathbf{8}$ and small amounts of $\mathbf{1}$. Over time, $\mathbf{8}$ in solution converted to $\mathbf{1}$. Crystals suitable for XRD were grown in a saturated, cold pentane:diethyl ether (2:1) solution under an ethylene atmosphere. ${ }^{1} \mathrm{H}$ NMR $\left(\mathrm{C}_{6} \mathrm{D}_{6}, 300 \mathrm{MHz}\right): \delta 33.1(1 \mathrm{H})$, $\delta 28.8(1 \mathrm{H}), \delta 18.7(4 \mathrm{H}), \delta 13.3(1 \mathrm{H}), \delta 5.25\left(\mathrm{~s}\right.$, free $\left.\mathrm{C}_{2} \mathrm{H}_{4}\right), \delta 4.9(3 \mathrm{H}), \delta 4.1(1 \mathrm{H}), \delta 1.9$ $(2 \mathrm{H}), \delta-3.0(10 \mathrm{H}), \delta-6.2(11 \mathrm{H}), \delta-9.2(11 \mathrm{H}), \delta-10.0(3 \mathrm{H})$. UV-Vis (THF, nm $\left.\left\{\mathrm{cm}^{-1} \mathrm{M}^{-1}\right\}\right): 309$ \{shoulder, 6032$\}, 553\{1804\}, 938\{418\} . \mu_{\mathrm{eff}}\left(\mathrm{C}_{6} \mathrm{D}_{6}\right.$, method of Evans, $\left.20^{\circ} \mathrm{C}\right): 3.2 \mu_{\mathrm{B}}(S=1)$. Anal.: Elemental analysis could not be obtained because of the instability of the compound under dynamic vacuum.

Synthesis of (TPBH)Fe( $\left.\mathbf{C}_{2} \mathbf{P h}\right)(9)$-Phenylacetylene $(40.8 \mathrm{mg}, 400 \mu \mathrm{mol})$ was added to a $\mathrm{C}_{6} \mathrm{H}_{6}$ solution $(5 \mathrm{~mL})$ of $\mathbf{3}(9.0 \mathrm{mg}, 13 \mu \mathrm{mol})$, immediately giving a gray solution. Removal of the solvent in vacuo yielded a black powder of $9(10 \mathrm{mg}, 100 \%) .{ }^{1} \mathrm{H}$ NMR $\left(\mathrm{C}_{6} \mathrm{D}_{6}, 300 \mathrm{MHz}\right): \delta 28.8(3 \mathrm{H}), \delta 13.1(4 \mathrm{H}), \delta 4.7(18 \mathrm{H}), \delta 2.6(2 \mathrm{H}), \delta 2.3(4 \mathrm{H}), \delta 1.2(2 \mathrm{H})$, $\delta-29.3(1 \mathrm{H}), \delta-30.9(5 \mathrm{H}) . \mu_{\mathrm{eff}}\left(\mathrm{C}_{6} \mathrm{D}_{6}\right.$, method of Evans, $\left.20{ }^{\circ} \mathrm{C}\right): 5.1 \mu_{\mathrm{B}}(S=2)$. UV-Vis (THF, nm $\left.\left\{\mathrm{cm}^{-1} \mathrm{M}^{-1}\right\}\right): 325\{20670\}, 439\{1051\}, 479\{971\}, 522\{955\}, 601$ (br abs extending from 400 to $700 \mathrm{~nm}, 930\}, 883\{1466\}$. IR $\left(\mathrm{KBr}, \mathrm{cm}^{-1}\right): 2040$ (s, C $\left.\equiv \mathrm{C}\right), 2490$ (m, B-H). Anal.: Calc'd for $\mathrm{C}_{44} \mathrm{H}_{60} \mathrm{FeP}_{3} \mathrm{~B}: \mathrm{C}, 70.60 ; \mathrm{H}, 8.08$. Found: C, 70.39; H, 7.89. 
Synthesis of (TPBD)Fe( $\left.\mathrm{C}_{2} \mathrm{Ph}\right)$ - The B-D labeled complex of 9 was generated by the same method described for 9, except that $\mathrm{PhC}_{2} \mathrm{H}$ was replaced with $\mathrm{PhC}_{2} \mathrm{D}$. The ${ }^{1} \mathrm{H}$ NMR spectrum was identical to 10. IR (thin film, $\mathrm{cm}^{-1}$ ): 1826 (br m, B-D; predicted 1832).

Synthesis of (TPBH)Fe( $\mathbf{C}_{\mathbf{2}}$ Tol) (10)—Tolylacetylene $(16.1 \mathrm{mg}, 138 \mu \mathrm{mol})$ was added to a $\mathrm{C}_{6} \mathrm{H}_{6}$ solution $(5 \mathrm{~mL})$ of $\mathbf{3}(22.9 \mathrm{mg}, 33.0 \mu \mathrm{mol})$, immediately giving a gray solution. Removal of the solvent in vacuo yielded a black powder of $\mathbf{1 0}(24.0 \mathrm{mg} 100 \%)$. Black XRD quality crystals of $\mathbf{1 0}$ were grown by diffusion of hexamethyldisiloxane into a concentrated THF solution of 10. ${ }^{1} \mathrm{H}$ NMR $\left(\mathrm{C}_{6} \mathrm{D}_{6}, 300 \mathrm{MHz}\right): \delta 44.1(1 \mathrm{H}), \delta 29.4(1 \mathrm{H}), \delta 13.3(1 \mathrm{H}), \delta$ $4.6(2 \mathrm{H}), \delta 3.3(1 \mathrm{H}), \delta 2.7(2 \mathrm{H}), \delta 2.3(4 \mathrm{H}), \delta 1.8(2 \mathrm{H}), \delta-32.3(1 \mathrm{H}) . \mu_{\mathrm{eff}}\left(\mathrm{C}_{6} \mathrm{D}_{6}\right.$, method of Evans, $\left.20^{\circ} \mathrm{C}\right): 5.2 \mu_{\mathrm{B}}(S=2)$. UV-Vis (THF, nm $\left.\left\{\mathrm{cm}^{-1} \mathrm{M}^{-1}\right\}\right): 326\{24476\}, 444\{1243\}$, $486\{1138\}, 527$ \{shoulder, 975$\}, 624(915\}, 887\{1575\}$. IR $\left(\mathrm{KBr}, \mathrm{cm}^{-1}\right): 2039(\mathrm{~s}, \mathrm{C} \equiv \mathrm{C})$, 2500 (m, B-H). Anal.: Calc'd for $\mathrm{C}_{45} \mathrm{H}_{62} \mathrm{FeP}_{3} \mathrm{~B}$ : C, 70.88; H, 8.20. Found: C, 70.44; H, 7.80 .

Synthesis of (TPBD)Fe( $\mathbf{C}_{\mathbf{2}}$ Tol)-The B-D labeled complex of $\mathbf{1 0}$ was generated by the same method described for 10, except that $\mathrm{TolC}_{2} \mathrm{H}$ was replaced with $\mathrm{TolC}_{2} \mathrm{D}$. The ${ }^{1} \mathrm{H}$ NMR spectrum was identical to 10. IR (thin film, $\mathrm{cm}^{-1}$ ): 1824 (br m, B-D; predicted 1841).

Synthesis of 11-A yellow, $\mathrm{C}_{6} \mathrm{H}_{6}$ solution of $\mathbf{1}(18.2 \mathrm{mg}, 27 \mu \mathrm{mol})$ was heated in a JYoung NMR tube under $\mathrm{H}_{2}(1 \mathrm{~atm})$ at $80^{\circ} \mathrm{C}$ for $2 \mathrm{~h}$, giving a turbid red-purple solution. The solvent was removed in vacuo, and the dark crude material was redissolved in hexamethyldisiloxane $(3 \mathrm{~mL})$ and filtered through a glass frit to remove a black solid (presumably iron metal). Removal of the solvent in vacuo gave a purple solid that is a mixture of $\mathbf{1 1}$ ( 1 equiv) and diisopropyl-phosphino-benzene ( ${ }^{i} \mathrm{Pr} 2 \mathrm{PPh}, 1$ equiv). Orange XRD quality crystals of $\mathbf{1 1}$ can be grown from slow evaporation of a concentrated hexamethyldisiloxane solution of $\mathbf{1 1}$ at room temperature (5.1 $\mathrm{mg}, 18 \%)$. Dissolution of these crystals by heating in benzene or THF results in decomposition. Therefore, spectral data is reported on the mixture of $\mathbf{1 1}$ with ${ }^{i}{ }^{{ }_{\mathrm{Pr}} 2} \mathrm{PPh}$. Compound $\mathbf{1 1}$ appears to be fluxional at RT. ${ }^{1} \mathrm{H}$ NMR $\left(\mathrm{C}_{6} \mathrm{D}_{6}, 300 \mathrm{MHz}\right): \delta 8.4(4 \mathrm{H}, \mathrm{s}, \mathrm{Ar}-H), \delta 7.6(4 \mathrm{H}, \mathrm{s}, \mathrm{Ar}-H), \delta 7.5\left(3 \mathrm{H}, \mathrm{d},{ }^{2} J_{\mathrm{H}-\mathrm{P}}\right.$ $=6 \mathrm{~Hz}, \mathrm{Ar}-H), \delta 2.7\left(1 \mathrm{H}, \mathrm{d},{ }^{2} J_{\mathrm{H}-\mathrm{P}}=6 \mathrm{~Hz}, \mathrm{PC} H\right), \delta 2.5(1 \mathrm{H}, \mathrm{s}, \mathrm{PC} H), \delta 1.9\left(1 \mathrm{H}\right.$, quart, ${ }^{3} J_{\mathrm{H}-\mathrm{H}}$ $=6 \mathrm{~Hz}, \mathrm{PCH}), \delta 1.3\left(6 \mathrm{H}, \mathrm{d}-\mathrm{d},{ }^{3} \mathrm{~J}_{\mathrm{P}-\mathrm{H}}=4 \mathrm{~Hz},{ }^{3} \mathrm{~J}_{\mathrm{H}-\mathrm{H}}=2 \mathrm{~Hz}, \mathrm{CH}\right), \delta 1.2\left(6 \mathrm{H}, \mathrm{d},{ }^{3} J_{\mathrm{H}-\mathrm{H}}=3 \mathrm{~Hz}\right.$, $\left.\mathrm{CH}_{3}\right), \delta 1.1\left(6 \mathrm{H}\right.$, quart, $\left.{ }^{3} J_{\mathrm{P}-\mathrm{H}}=4 \mathrm{~Hz},{ }^{3} J_{\mathrm{H}-\mathrm{H}}=2 \mathrm{~Hz}, \mathrm{CH}_{3}\right), 0.9\left(12 \mathrm{H}, \mathrm{m}, \mathrm{CH}_{3}\right),-17.0(0.25 \mathrm{H}$, t, $\left.{ }^{2} J_{\mathrm{H}-\mathrm{P}}=36 \mathrm{~Hz}, \mathrm{~B}-H\right) \cdot{ }^{13} \mathrm{C} \mathrm{NMR}\left(\mathrm{C}_{6} \mathrm{D}_{6}, 125 \mathrm{MHz}\right): \delta 157.4\left(\mathrm{br} \mathrm{s}, C^{\mathrm{Ar}}\right), \delta 144.2\left(\mathrm{br} \mathrm{s}, \mathrm{C}^{\mathrm{Ar}}\right)$, $\delta 134.9\left(\mathrm{~d},{ }^{2} J_{\mathrm{C}-\mathrm{P}}=19 \mathrm{~Hz}, \mathrm{C}^{\mathrm{Ar}}\right), \delta 130.5\left(\mathrm{~s}, \mathrm{C}^{\mathrm{Ar}}\right), \delta 129.3\left(\mathrm{~s}, \mathrm{C}^{\mathrm{Ar}}\right), \delta 125.7\left(\mathrm{~d},{ }^{2} J_{\mathrm{C}-\mathrm{P}}=23 \mathrm{~Hz}\right.$, $\mathrm{C}^{\mathrm{Ar}}$ ), $\delta 25.5$ (br s, PCH), $\delta 24.9$ (br s, PCH), $\delta 24.4$ (br s, PCH), $\delta 23.7$ (br s, PCH), $\delta 23.1$ (br s, PCH), $\delta 20.0\left(\mathrm{~m}, C_{3}\right), \delta 19.4\left(\mathrm{~m}, C_{3}\right), \delta 18.2\left(\mathrm{~m}, C_{3}\right) .{ }^{31} \mathrm{P} \mathrm{NMR}\left(\mathrm{C}_{6} \mathrm{D}_{6}, 121\right.$ MHz): $\delta 99.1$ (4P, s), $\delta 9.5$ (2P, s). ${ }^{11} \mathrm{~B}$ NMR $\left(\mathrm{C}_{6} \mathrm{D}_{6}, 128 \mathrm{MHz}\right): \delta 41.0$ (br). UV-Vis (THF, $\left.\mathrm{nm}\left\{\mathrm{cm}^{-1} \mathrm{M}^{-1}\right\}\right): 264$ s shoulder, 31650$\}, 520\{826\} . \mathrm{IR}\left(\mathrm{KBr}, \mathrm{cm}^{-1}\right): 2088$ (s, B-H), 1838 (m, B-H). Anal.: Calc'd for $\mathrm{C}_{51} \mathrm{H}_{86} \mathrm{FeP}_{4} \mathrm{~B}_{2} \mathrm{Si}$ (i.e., $11+\mathrm{Me}_{3} \mathrm{SiH}$ ): C, 65.96; H, 9.33. Found: C, 65.70; H, 9.16.

Synthesis of $\left(\mathrm{SiP}^{i P r}\right) \mathbf{F e}\left(\mathrm{H}_{2}\right)(\mathbf{H})$ - In a $100 \mathrm{~mL}$ Schlenk tube a red solution of $\left(\mathrm{SiP}^{\mathrm{PPr}}{ }_{3}\right) \mathrm{Fe}(\mathrm{Me})(1.05 \mathrm{~g}, 1.547 \mathrm{mmol})$ in $\mathrm{C}_{6} \mathrm{H}_{6}(50 \mathrm{~mL})$ was degassed by freeze-pump-thaw (3x). $\mathrm{H}_{2}$ gas $(1 \mathrm{~atm})$ was charged into the reaction mixture. The reaction was heated at $60{ }^{\circ} \mathrm{C}$ for over a week. The reaction solution was then quickly filtered through Celite and volatiles were removed in vacuo to give a light yellow powder. The solid was collected on a glass-frit and washed with pentane $(3 \mathrm{~mL} \times 2)$. The resulting product $\left(\mathbf{S i P}^{i \mathbf{P r}}{ }_{\mathbf{3}}\right) \mathbf{F e}\left(\mathbf{H}_{2}\right)(\mathbf{H})(950 \mathrm{mg}$, $1.425 \mathrm{mmol}, 92 \%)$ was obtained as a light yellow powder after drying under vacuum. ${ }^{1} \mathrm{H}$ NMR $\left(\mathrm{C}_{6} \mathrm{D}_{6}, 300 \mathrm{MHz}\right): \delta 8.3\left(3 \mathrm{H}, \mathrm{d},{ }^{3} J_{\mathrm{H}-\mathrm{P}}=6.8 \mathrm{~Hz}, \mathrm{Ar}-H\right), \delta 7.3(3 \mathrm{H}, \mathrm{m}, \mathrm{Ar}-H), \delta 7.2$ $\left(3 \mathrm{H}, \mathrm{t},{ }^{3} \mathrm{~J}_{\mathrm{H}-\mathrm{H}}=7.2 \mathrm{~Hz}, \mathrm{Ar}-H\right), \delta 7.1\left(3 \mathrm{H}, \mathrm{t},{ }^{3} J_{\mathrm{H}-\mathrm{H}}=7 \mathrm{~Hz}, \mathrm{Ar}-H\right), \delta 4.5\left(\mathrm{~s}\right.$, free $\left.\mathrm{H}_{2}\right), \delta 2.2$ $(6 \mathrm{H}, \mathrm{m}, \mathrm{PC} H), \delta 1.0\left(18 \mathrm{H}, \mathrm{m}, \mathrm{CH}_{3}\right), \delta 0.8\left(18 \mathrm{H}\right.$, br s, $\left.\mathrm{CH}_{3}\right), \delta 0.16\left(\mathrm{~s}\right.$, free $\left.\mathrm{CH}_{4}\right), \delta-10.0$ 
(3H, quin, $\left.{ }^{2} J_{\mathrm{P}-\mathrm{H}}=18.4 \mathrm{~Hz}, \mathrm{Fe}-H\right) . \mathrm{T}_{1 \min }\left(d_{8}\right.$-toluene): $32 \mathrm{~ms}\left(\delta-10.0,-30{ }^{\circ} \mathrm{C}\right) .{ }^{31} \mathrm{P}$ NMR $\left(\mathrm{C}_{6} \mathrm{D}_{6}, 121 \mathrm{MHz}\right): \delta 100(\mathrm{br}) ;\left(d_{8}-\mathrm{Tol}, 300 \mathrm{MHz},-80{ }^{\circ} \mathrm{C}\right): \delta 117.9\left(\mathrm{~d},{ }^{3} J_{\mathrm{P}-\mathrm{P}}=43.5 \mathrm{~Hz}\right), \delta$ 94.7 (bs), $\delta 84.7\left(\mathrm{~d},{ }^{3} J_{\mathrm{P}-\mathrm{P}}=43.5 \mathrm{~Hz}\right) .{ }^{13} \mathrm{C}$ NMR (THF with 1 drop of $\left.\mathrm{C}_{6} \mathrm{D}_{6}, 125 \mathrm{MHz}\right): \delta$ $157.3\left(\mathrm{~d}, J_{\mathrm{C}-\mathrm{P}}=22.5 \mathrm{~Hz}, \mathrm{C}^{\mathrm{Ar}}\right), \delta 150.5\left(\mathrm{~d}, J_{\mathrm{C}-\mathrm{P}}=21.3 \mathrm{~Hz}, \mathrm{C}^{\mathrm{Ar}}\right), \delta 130.1\left(\mathrm{~d}, J_{\mathrm{C}-\mathrm{P}}=9.3 \mathrm{~Hz}\right.$, $\left.\mathrm{C}^{\mathrm{Ar}}\right), \delta 128.6\left(\mathrm{~s}, \mathrm{C}^{\mathrm{Ar}}\right), \delta 127.4\left(\mathrm{~s} \mathrm{C} \mathrm{Cr}^{\mathrm{Ar}}\right), \delta 126.0\left(\mathrm{~d}, J_{\mathrm{C}-\mathrm{P}}=2.5 \mathrm{~Hz}, \mathrm{C}^{\mathrm{Ar}}\right), \delta 29.0(\mathrm{br} \mathrm{s}, \mathrm{PCH}), \delta$ 20.4 (br s, $\mathrm{CH}_{3}$ ), $\delta 19.2$ (br s, $\mathrm{CH}_{3}$ ), UV-Vis (THF, nm $\left.\left\{\mathrm{cm}^{-1} \mathrm{M}^{-1}\right\}\right): 353\{3040\}$. IR ( $\mathrm{KBr}$ pellet; $\mathrm{cm}^{-1}$ ): 1941 (w, Fe-H). Anal.: Elemental analysis could not be obtained because of the instability of the compound under prolonged exposure to $\mathrm{N}_{2}$.

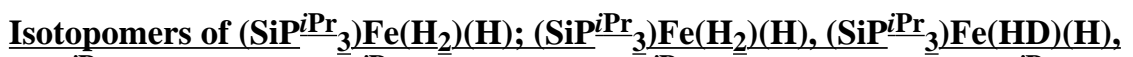

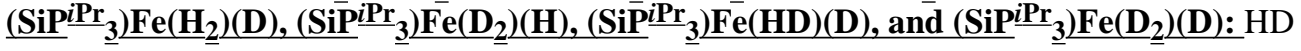
gas was generated by the method described above and charged into a J-young tube containing a degassed solution of $\left.\operatorname{SiP}^{i P r}{ }_{3}\right) \mathbf{F e}(\mathbf{M e})$ in $\mathrm{C}_{6} \mathrm{D}_{6}$. The solution was heated at $60{ }^{\circ} \mathrm{C}$ for over a week. Monitoring the progress of the reaction by ${ }^{1} \mathrm{H}$ NMR revealed the gradual disappearance of $\mathbf{1}$ and formation of diamagnetic isotopomers $\left(\operatorname{SiP}^{i P r}{ }_{3}\right) \mathbf{F e}\left(\mathbf{H}_{2}\right)(\mathbf{H})$. Spectroscopic features in the ${ }^{1} \mathrm{H}$ NMR spectrum were identical to $\left(\mathbf{S i P}^{i \mathbf{P r}}{ }_{3}\right) \mathbf{F e}\left(\mathbf{H}_{2}\right)(\mathbf{H})$ except for the hydridic proton resonances, where isotopologues were observed. ${ }^{1} \mathrm{H}\left\{{ }^{31} \mathrm{P}\right\}$ $\operatorname{NMR}\left(\mathrm{C}_{6} \mathrm{D}_{6}, 300 \mathrm{MHz}\right): \delta-10.0\left(3 \mathrm{H}\right.$, quart, $\left.{ }^{2} \mathrm{~J}_{\mathrm{P}-\mathrm{H}}=18.4 \mathrm{~Hz}, \mathrm{H}_{3}\right), \delta-10.0\left(\mathrm{t},{ }^{1} J_{\mathrm{H}-\mathrm{D}}=9.5\right.$ $\mathrm{Hz}, \mathrm{H}_{2} \mathrm{D}$ ), $\delta-10.23$ (quin, ${ }^{1} J_{\mathrm{H}-\mathrm{D}}=9.3 \mathrm{~Hz}, \mathrm{HD}_{2}$ ).

Synthesis of $\left(\mathrm{SiP}^{\mathrm{iPr}}{ }_{3}\right) \mathrm{Fe}(\mathrm{CO})(\mathrm{H})$ - In a $50 \mathrm{~mL}$ Schlenk tube a yellow solution of $\left(\mathbf{S i P}^{i \mathbf{P r}}{ }_{3}\right) \mathbf{F e}\left(\mathbf{H}_{2}\right)$ (H) (330 mg, $\left.0.495 \mathrm{mmol}\right)$ in $\mathrm{C}_{6} \mathrm{H}_{6}(20 \mathrm{~mL})$ was freeze-pump-thawed (3x). The solution was charged with $\mathrm{CO}(1 \mathrm{~atm})$. The reaction was mixed overnight at RT and then for $1 \mathrm{~h}$ at $60^{\circ} \mathrm{C}$, resulting in a light yellow solution. After completion, the solution was degassed by freeze-pump-thaw (3x). The solution was filtered through Celite, and the volatiles were removed in vacuo to give a light yellow powder. The solid was collected on a glass-frit and washed with pentane $(5 \mathrm{~mL} \times 3)$. Removal of the solvent in vacuo yields $\left(\mathbf{S i P}^{\mathbf{P P r}}{ }_{3}\right) \mathbf{F e}(\mathbf{C O})(\mathbf{H})(266 \mathrm{mg}, 0.384 \mathrm{mmol}, 78 \%)$ as a light yellow powder. Crystals suitable for X-ray diffraction were obtained by RT evaporation of a pentane solution of $\left(\mathrm{SiP}^{\mathbf{i P r}}{ }_{3}\right) \mathbf{F e}(\mathbf{C O})(\mathbf{H}) .{ }^{1} \mathrm{H}$ NMR $\left(d_{8}\right.$-toluene, $\left.300 \mathrm{MHz}\right): \delta 8.2\left(2 \mathrm{H}, \mathrm{d},{ }^{3} J_{\mathrm{H}-\mathrm{H}}=7.2 \mathrm{~Hz}\right), \delta 8.1$ $\left(1 \mathrm{H}, \mathrm{d},{ }^{3} J_{\mathrm{H}-\mathrm{H}}=7.2 \mathrm{~Hz}\right), \delta 7.3(3 \mathrm{H}, \mathrm{m}), \delta 7.2(3 \mathrm{H}, \mathrm{m}), \delta 7.1(3 \mathrm{H}, \mathrm{m}), \delta 2.7(2 \mathrm{H}, \mathrm{m}), \delta 2.4$ $(2 \mathrm{H}, \mathrm{m}), \delta 2.2(2 \mathrm{H}, \mathrm{m}), \delta 1.5\left(6 \mathrm{H}, \mathrm{d}-\mathrm{d},{ }^{3} J_{\mathrm{H}-\mathrm{P}}=15.2 \mathrm{~Hz},{ }^{3} J_{\mathrm{H}-\mathrm{P}}=6.8 \mathrm{~Hz}\right), \delta 1.3(6 \mathrm{H}, \mathrm{m}), \delta 1.1$ $\left(6 \mathrm{H}, \mathrm{d}-\mathrm{d},{ }^{3} J_{\mathrm{H}-\mathrm{P}}=12.6 \mathrm{~Hz},{ }^{3} J_{\mathrm{H}-\mathrm{H}}=6.6 \mathrm{~Hz}\right), \delta 0.8(12 \mathrm{H}, \mathrm{m}), \delta 0.5(6 \mathrm{H}, \mathrm{s}), \delta-14.9(1 \mathrm{H}, \mathrm{t}-$ $\left.\mathrm{d},{ }^{3} J_{\mathrm{H}-\mathrm{Pcis}}=81.0 \mathrm{~Hz},{ }^{3} J_{\mathrm{H}-\mathrm{Ptrans}}=14.1 \mathrm{~Hz}\right) .{ }^{31} \mathrm{P}$ NMR $\left(\mathrm{C}_{6} \mathrm{D}_{6}, 121 \mathrm{MHz}, \mathrm{RT}\right): \delta 88.0(\mathrm{br}), \delta$ $90.0(\mathrm{~s}) ;\left(d_{8}\right.$-toluene, $\left.121 \mathrm{MHz},-80{ }^{\circ} \mathrm{C}\right): \delta 109.9\left(\mathrm{t},{ }^{3} J_{\mathrm{P}-\mathrm{P}}=65 \mathrm{~Hz},{ }^{3} J_{\mathrm{P}-\mathrm{H}}=80 \mathrm{~Hz}\right), \delta 90.0$ $(\mathrm{s}), \delta 77.9\left(\mathrm{t},{ }^{3} J_{\mathrm{P}-\mathrm{P}}=65 \mathrm{~Hz},{ }^{3} J_{\mathrm{P}-\mathrm{H}}=80 \mathrm{~Hz}\right.$ ). ${ }^{13} \mathrm{C}$ NMR (THF with 1 drop of $\mathrm{C}_{6} \mathrm{D}_{6}, 125$ MHz): $\delta 223.0\left(\mathrm{~d},{ }^{2} J_{\mathrm{C}-\mathrm{P}}=6.3 \mathrm{~Hz}, C \mathrm{O}\right), \delta 157.2\left(\mathrm{~d}, J_{\mathrm{C}-\mathrm{P}}=8.8 \mathrm{~Hz}, C^{\mathrm{Ar}}\right), \delta 155.2\left(\mathrm{~d}, J_{\mathrm{C}-\mathrm{P}}=\right.$ $\left.10.6 \mathrm{~Hz}, C^{\mathrm{Ar}}\right), \delta 150.5\left(\mathrm{~d}, J_{\mathrm{C}-\mathrm{P}}=11.3 \mathrm{~Hz}, C^{\mathrm{Ar}}\right), \delta 150.2\left(\mathrm{~d}, J_{\mathrm{C}-\mathrm{P}}=8.8 \mathrm{~Hz}, C^{\mathrm{Ar}}\right), \delta 148.6(\mathrm{~d}$, $\left.J_{\mathrm{C}-\mathrm{P}}=18.1 \mathrm{~Hz}, C^{\mathrm{Ar}}\right), \delta 132.4\left(\mathrm{~d}, J_{\mathrm{C}-\mathrm{P}}=9.4 \mathrm{~Hz}, C^{\mathrm{Ar}}\right), \delta 131.9\left(\mathrm{~d}, J_{\mathrm{C}-\mathrm{P}}=8.8 \mathrm{~Hz}, C^{\mathrm{Ar}}\right), \delta$ $130.9\left(\mathrm{~s}, C^{\mathrm{Ar}}\right), \delta 128.3\left(\mathrm{~s}, C^{\mathrm{Ar}}\right), \delta 128.5\left(\mathrm{~s}, C^{\mathrm{Ar}}\right), \delta 127.1\left(\mathrm{~s}, C^{\mathrm{Ar}}\right), \delta 126.8\left(\mathrm{~s}, C^{\mathrm{Ar}}\right), \delta 126.4$ (s, $\left.C^{\mathrm{Ar}}\right), \delta 125.8\left(\mathrm{~s}, C^{\mathrm{Ar}}\right), \delta 124.7\left(\mathrm{~s}, C^{\mathrm{Ar}}\right), \delta 32.4(\mathrm{~s}, \mathrm{PCH}), \delta 30.7$ (s, PCH), $\delta 30.0(\mathrm{~s}$, $\mathrm{PCH}), \delta 29.6$ (s, PCH), $\delta 28.7$ (s, $\mathrm{PCH}), \delta 22.8\left(\mathrm{~s}, \mathrm{CH}_{3}\right), \delta 22.1\left(\mathrm{~s}, \mathrm{CH}_{3}\right), \delta 20.2\left(\mathrm{~s}, \mathrm{CH}_{3}\right), \delta$ $19.5\left(\mathrm{~s}, \mathrm{CH}_{3}\right), \delta 19.2\left(\mathrm{~s}, \mathrm{CH}_{3}\right), \delta 19.1\left(\mathrm{~s}, C_{3}\right), \delta 18.9\left(\mathrm{~s}, C_{\mathrm{H}}\right), \delta 18.0\left(\mathrm{~s}, \mathrm{CH}_{3}\right)$. UV-Vis (THF, nm $\left.\left\{\mathrm{cm}^{-1} \mathrm{M}^{-1}\right\}\right): 340\{2,050\}, 400\{1,500\}$. IR (KBr pellet; $\left.\mathrm{cm}^{-1}\right): 1882$ (s, C $\left.\equiv \mathrm{O}\right)$, 1944 (m, Fe-H). Anal.: Calc'd for $\mathrm{C}_{37} \mathrm{H}_{57} \mathrm{FeOP}_{3} \mathrm{Si}$ : C, 64.16; H, 8.00. Found: C, 64.15; H, 8.13 .

Synthesis of $\left(\mathrm{SiP}^{\mathrm{PPr}}{ }_{3}\right) \mathrm{Fe}\left({ }^{13} \mathrm{CO}\right)(\mathrm{H})$-In a J-Young NMR tube an orange $\mathrm{C}_{6} \mathrm{D}_{6}$ solution of $\left(\mathbf{S i P}^{i \mathbf{P r}}{ }_{3}\right) \mathbf{F e}\left(\mathbf{H}_{2}\right)(\mathbf{H})$ was degassed by three freeze-pump-thaw (3x). Subsequently, ${ }^{13} \mathrm{CO}$ $(1 \mathrm{~atm})$ was added and the reaction was allowed to mix overnight at RT. The ${ }^{1} \mathrm{H}$ NMR spectrum was identical to $\left(\mathbf{S i P}^{i \mathbf{P r}}{ }_{3}\right) \mathbf{F e}(\mathbf{C O})(\mathbf{H})$. IR $\left(\mathrm{KBr} ; \mathrm{cm}^{1}\right): 1836\left(\mathrm{~s},{ }^{13} \mathrm{C} \equiv \mathrm{O}\right)$. 


\section{Generation of (TPBH)Fe(Et) (A)}

Compound $\mathbf{A}$ was observed as an intermediate of catalytic ethylene hydrogenation under the reaction conditions described in section "Catalytic Hydrogenation Studies." We were also able to generate A starting from complex $\mathbf{8}$. This procedure described below is more amendable to observing $\mathbf{A}$ spectroscopically. A dark yellow $\mathrm{C}_{6} \mathrm{D}_{6}$ solution $(0.5 \mathrm{~mL})$ of $\mathbf{8}$ $(2.8 \mathrm{mg}, 4.2 \mu \mathrm{mol})$ under ethylene $(1 \mathrm{~atm})$ in a J-Young tube was frozen $\left(-196{ }^{\circ} \mathrm{C}\right)$ and $\mathrm{H}_{2}$ was added (1 atm). The reaction was thawed and quickly mixed only immediately prior to measuring the ${ }^{1} \mathrm{H}$ NMR spectrum, revealing a mixture of $\mathbf{8}$ and $\mathbf{A}$. Further mixing of the solution for ca. 45 min yielded a purple solution of $\mathbf{A}$ with a small residual amount of $\mathbf{8}$ by ${ }^{1} \mathrm{H}$ NMR spectroscopy. Free $\mathrm{C}_{2} \mathrm{H}_{4}, \mathrm{C}_{2} \mathrm{H}_{6}$, and $\mathrm{H}_{2}$ were also observed in the ${ }^{1} \mathrm{H}$ NMR spectrum. Compound $\mathbf{A}$ could not be isolated as a solid due its instability. For example, an ATR IR spectrum of a thin film of the reaction mixture obtained by solvent evaporation under an $\mathrm{N}_{2}$ atmosphere over a period less than $30 \mathrm{sec}$ gave vibrational bands diagnostic of 1, 2, and A. ${ }^{1} \mathrm{H}$ NMR $\left(\mathrm{C}_{6} \mathrm{D}_{6}, 300 \mathrm{MHz}\right): \delta 17.3(1 \mathrm{H}), \delta 6.6(1 \mathrm{H}), \delta 5.26\left(\mathrm{~s}\right.$, free $\left.\mathrm{C}_{2} \mathrm{H}_{4}\right), \delta 4.4$ $(1 \mathrm{H}), \delta 4.47\left(\mathrm{br} \mathrm{s}\right.$, free $\left.\mathrm{H}_{2}\right), \delta 3.3(2 \mathrm{H}), 0.80\left(\mathrm{~s}\right.$, free $\left.\mathrm{C}_{2} \mathrm{H}_{6}\right), \delta-1.9(8 \mathrm{H}), \delta-5.5(6 \mathrm{H})$. IR (thin film; $\mathrm{cm}^{-1}$ ): 2470 (br s, B-H of A), $2069\left(\mathrm{~m}, \mathrm{~N} \equiv \mathrm{N}\right.$ of $\left.(\mathrm{TPB})(\mu-\mathrm{H}) \mathrm{Fe}\left(\mathrm{N}_{2}\right)(\mathrm{H}) 2\right), 2009$ $\left(\mathrm{s}, \mathrm{N} \equiv \mathrm{N}\right.$ of $\left.(\mathrm{TPB}) \mathrm{Fe}\left(\mathrm{N}_{2}\right) \mathbf{1}\right)$. UV-Vis, obtained $45 \mathrm{~min}$ after exposing $\mathbf{A}$ under $1 \mathrm{~atm}$ of ethylene to $1 \mathrm{~atm}$ of $\mathrm{H}_{2}$ (THF, $\mathrm{nm}\left\{\mathrm{cm}^{-1} \mathrm{M}^{-1}\right\}$ ): $325\{20670\}, 439\{1051\}, 479\{971\}, 522$ $\{955\}, 601$ (br abs extending from 400 to $600 \mathrm{~nm}, 930\}, 883$ \{1466\}. Magnetic data could not be obtained due to residual $\mathbf{1 0}$ in the reaction mixture. Anal.: Elemental analysis could not be obtained because of the instability of the compound under dynamic vacuum.

\section{Catalytic Hydrogenation Studies}

Compound $1(0.045 \mathrm{~g}, 0.07 \mathrm{mmol})$ and ferrocene $(0.012 \mathrm{~g}, 0.07 \mathrm{mmol})$ were dissolved in 1.5 $\mathrm{mL}$ of $\mathrm{C}_{6} \mathrm{D}_{6}$, giving a $0.045 \mathrm{M}$ precatalyst stock solution. Ferrocene was used as an internal ${ }^{1} \mathrm{H}$ NMR integration standard and did not affect the rates of hydrogenation. For a catalytic run, $0.1 \mathrm{~mL}$ of the stock solution was taken and mixed with $0.35 \mathrm{~mL}$ of $\mathrm{C}_{6} \mathrm{D}_{6}$, and 30 equiv of substrate in a J-Young NMR tube ( $3.2 \mathrm{~mL}$ capacity). For styrene hydrogenation, this equates to $0.01 \mathrm{M} 1$ and $0.3 \mathrm{M}$ styrene. For phenylacetylene hydrogenation, this equates to $0.01 \mathrm{M} 1$ and $0.29 \mathrm{M}$ phenylacetylene. For ethylene hydrogenation, this equates to $0.01 \mathrm{M}$ 1 and $0.30 \mathrm{M}$ ethylene. The sample in the J-Young NMR tube was subsequently degassed by freeze-pump-thaw (3x) and backfilled with $1 \mathrm{~atm} \mathrm{H}_{2}(0.11 \mathrm{mmol})$. The J-Young NMR tube was continually inverted $\left(12 \mathrm{~min}^{-1}\right)$ to ensure adequate mass transfer. The tube was periodically refilled with $\mathrm{H}_{2}$ to maintain 1 atm of $\mathrm{H}_{2}$. All reactions were monitored periodically by ${ }^{1} \mathrm{H}$ NMR spectroscopy until $>95 \%$ completion. All reactions resulted in clean conversion of the substrate to the corresponding product. Catalytic runs in the presence of a drop of mercury or in the absence of ambient laboratory light had no affect on the reactions. Catalytic hydrogenations could also be cleanly effected by pre-generating 2 or 3 before the addition of the substrate.

\section{Supplementary Material}

Refer to Web version on PubMed Central for supplementary material.

\section{Acknowledgments}

We acknowledge the Gordon and Betty Moore Foundation and the NIH (GM070757) for funding. M.-E.M acknowledges a Fellowship for Advanced Researchers from the Swiss National Science Foundation. Dr. Charlene Tsay and Lawrence Henling are acknowledged for assistance with X-ray crystallography, and Dr. David VanderVelde is acknowledged for assistance with NMR spectroscopy. We acknowledge the Gordon and Betty Moore Foundation, the Beckman Institute, and the Sanofi-Aventis BRP at Caltech for their generous support of the Molecular Observatory. 


\section{References}

1. Hartwig, JF. Organotransition Metal Chemistry: From Bonding to Catalysis. University Science Books; 2010.

2. Bullock, RM., editor. Catalysis Without Precious Metals. Wiley-VCH; 2010.

3. For representative examples of mid-to-late first row transition metal catalysts that perform twoelectron transformations see: Bolm C, Legros J, Le Paih J, Zani L. Chem Rev. 2004; 104:62176254. [PubMed: 15584700] Hu X. Chem Sci. 2011; 2:1867-1886.Knijnenburg Q, Horton AD, van der Heijden H, Kooistra TM, Hetterscheid DGH, Smits JMM, de Briun B, Budzelaar PHM, Gal AW. J Mol Catal A. 2005; 232:151-159.Tondreau AM, Atienza CCH, Weller KJ, Nye SA, Lewis KM, Delis JGP, Chirik PJ. Science. 2012; 335:567-570. [PubMed: 22301315] Daida EJ, Peters JC. Inorg Chem. 2004; 43:7474-7585. [PubMed: 15530098] Federsel C, Boddien A, Jackstell R, Jennerjahn R, Dyson PJ, Scopelliti R, Laurenczy G, Beller M. Angew Chem, Int Ed. 2010; 49:9777-9780.

4. (a) Noyori R, Yamakawa M, Hashiguchi S. J Org Chem. 2001; 66:7931-7944. [PubMed: 11722188] (b) Morris RH. Chem Soc Rev. 2009; 38:2282-2291. [PubMed: 19623350] (c) Chakraborty S, Guan H. Dalton Trans. 2010; 39:7427-7436. [PubMed: 20505877] (d) Casey CP, Guan H. J Am Chem Soc. 2007; 129:5816-5817. [PubMed: 17439131] (e) Sui-Seng C, Freutel F, Lough AJ, Morris RH. Angew Chem, Int Ed. 2008; 47:940-943.(f) Langer R, Leitus G, Ben-David Y, Milstein D. Angew Chem, Int Ed. 2011; 50:2120-2124.

5. Tsoureas N, Kuo YY, Haddow MF, Owen GR. Chem Comm. 2011; 47:484-486. [PubMed: 20938529]

6. For discussions on the M-B bonding situation: Sircoglou M, Bontemps S, Mercy M, Saffon N, Takahashi M, Bouhadir G, Maron L, Bourissou D. Angew Chem, Int Ed. 2007; 46:85838586.Amgoune A, Bourissou D. Chem Comm. 2011; 47:859-871. [PubMed: 21103473] Hill AF. Organometallics. 2006; 25:4741-4743.Parkin G. Organometallics. 2006; 25:4744-4747.

7. (a) Owen GR. Chem Soc Rev. 2012; 41:3535-3546. [PubMed: 22331233] (b) Tsoureas N, Owen GR, Hamilton A, Orpen AG. Dalton Trans. 2008:6039-6044. [PubMed: 19082061]

8. (a) Crossley IR, Foreman MRSt-J, Hill AF, Owen GR, White AJP, Williams DJ, Willis AC. Organometallics. 2008; 27:381-386.(b) Crossley IR, Foreman MRSt-J, Hill AF, White AJ, Williams D. Chem Comm. 2005:221-223. [PubMed: 15724192] (c) Crossley IR, Hill AF, Willis AC. Organometallics. 2007; 26:3891-3895.(d) Crossley IR, Hill AF. Dalton Trans. 2008:201-203. [PubMed: 18097486] (e) Crossley IR, Hill AF, Willis AC. Organometallics. 2008; 27:312-315.(f) Hill AF, Smith MK, Wagler J. Organometallics. 2008; 27:2137-2140.(g) Crossley IR, Hill AF, Willis AC. Organometallics. 2009; 29:326-336.

9. Stephan DW, Erker G. Angew Chem, Int Ed. 2009; 49:46-76.

10. Harman WH, Peters JC. J Am Chem Soc. 2012; 134:5080-5082. [PubMed: 22380492]

11. Kameo H, Nakazawa H. Organometallics. 2012; 31:7476-7484.

12. (a) Moret ME, Peters JC. Angew Chem, Int Ed. 2011; 50:2063-2067.(b) Moret ME, Peters JC. J Am Chem Soc. 2011; 133:18118-18121. [PubMed: 22008018]

13. Bontemps S, Bouhadir G, Dyer PW, Miqueu K, Bourissou D. Inorg Chem. 2007; 46:5149-5151. [PubMed: 17523635]

14. The H-D coupling constant $\left(J_{\mathrm{H}-\mathrm{D}}\right)$ is also in principle an excellent distinguishing characteristic between the $\eta^{2}$-dihydrogen and dihydride ligands. ${ }^{15}$ Unfortunately, H-D coupling cannot be resolved in $\mathbf{3}$, likely due to fast exchange within the $\mathrm{H}_{\mathrm{n}} \mathrm{D}_{3-\mathrm{n}}$ unit and $\mathrm{H} / \mathrm{D}$ scrambling into the methine and terminal methyl positons on the isopropyl groups of the TPB ligand.

15. (a) Desrosiers PJ, Cai L, Lin Z, Richards R, Halpern J. J Am Chem Soc. 1991; 113:4173-4184.(b) Kubas GJ. Chem Rev. 2007; 107:4152-4205. [PubMed: 17927158] (c) Morris RH. Coord Chem Rev. 2008; 252:2381-2394.

16. Van der Sluys LS, Eckert J, Eisenstein O, Hall JH, Huffman JC, Jackson SA, Koetzle TF, Kubas GJ, Vergamini PJ, Caulton KG. J Am Chem Soc. 1990; 112:4831-4841.

17. Lee Y, Kinney RA, Hoffman BM, Peters JC. J Am Chem Soc. 2011; 133:16366-16369. [PubMed: 21954981]

18. Lee Y, Peters JC. J Am Chem Soc. 2011; 133:4438-4446. [PubMed: 21375250] 
19. Lee Y, Mankad NP, Peters JC. Nat Chem. 2010; 2:558-565. [PubMed: 20571574]

20. Bartell LS, Roth EA, Hollowell CD, Kuchitsu K, Young JE. J Chem Phys. 1965; 42:2683-2683.

21. Select iron-ethylene complexes of ferracyclopropane character: Zenneck U, Frank W. Angew

Chem, Int Ed. 1986; 25:831-833.Schneider JJ, Czap N, Blaser D, Boese R. J Am Chem Soc. 1999; 121:1409-1410.Bennett MA, Ditzel EJ, Hunter AD, Khan K, Kopp MR, Neumann H, Robertson GB, Zeh H. J Chem Soc, Dalton Trans. 2000:1733-1741.Fürstner A, Martin R, Krause H, Seidel G, Goddard R, Lehmann CW. J Am Chem Soc. 2008; 130:8773-8787. [PubMed: 18597432]

22. A similar paramagnetic $(S=2)$ iron ethyl-hydro-tris(pyrazolyl)borate complex: Shirasawa N,

Nguyet TT, Hikichi S, Moro-oka Y, Akita M. Organometallics. 2001; 20:3582-3598.

23. Marchand AP, Marchand NW. Tetrahedron Lett. 1971; 12:1365-1368.

24. Suess DLM, Tsay C, Peters JC. J Am Chem Soc. 2012; 134:14158-14164. [PubMed: 22891606]

25. (a) Reinhard N. Coord Chem Rev. 1982; 47:89-124.(b) Bianchini C, Laschi F, Masi D, Ottaviani FM, Pastor A, Peruzzini M, Zanello P, Zanobini F. J Am Chem Soc. 1993; 115:2723-2730.(c)

Field LD, George AV, Malouf EY, Slip IHM, Hambley TW. Organometallics. 1991; 10:38423848.

26. Tsay C, Peters JC. Chem Sci. 2012; 3:1313-1318.

27. Suess DLM, Peters JC. J Am Chem Soc. 2013 [Online early access]. 10.1021/ja400836u

28. Rubina M, Gevorgyan V. J Am Chem Soc. 2001; 123:11107-11108. [PubMed: 11686734] 

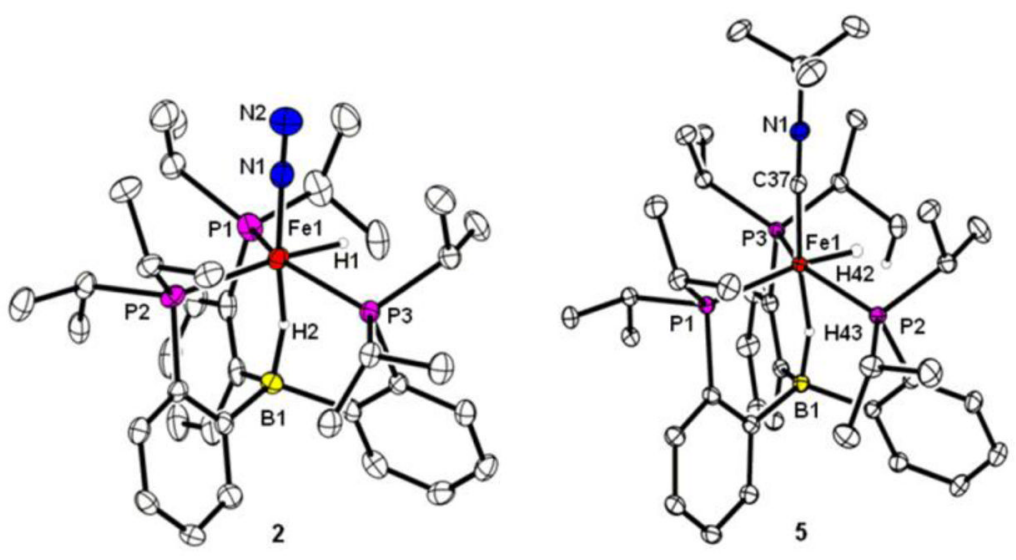

Figure 1.

XRD structures of $\mathbf{2}$ (left) and $\mathbf{5}$ (right). Ellipsoids shown at 50\% probability. Selected bond distances $(\AA): 2, \mathrm{Fe} 1-\mathrm{H} 1=1.42(2), \mathrm{Fe} 1-\mathrm{H} 2=1.49(2), \mathrm{B} 1-\mathrm{H} 2=1.17(2), \mathrm{Fe} 1-\mathrm{B} 1=2.604(3)$; 5, Fe1-H42 = 1.35(2), Fe1-H43 = 1.52(2), B1-H43 = 1.20(2), Fe1-B1 = 2.673(2). 


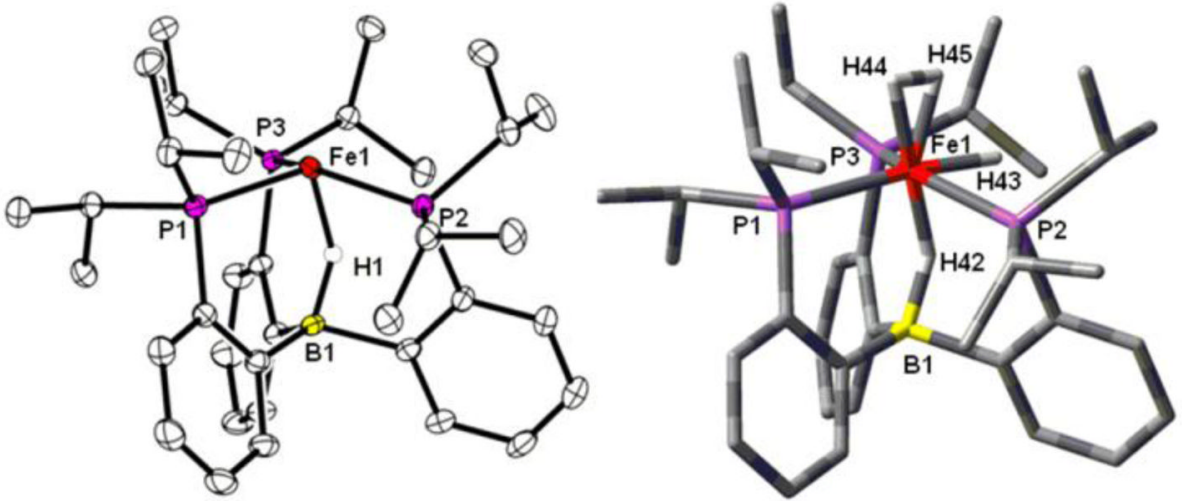

Figure 2.

XRD (left) and DFT optimized (right) structures of 3 . Ellipsoids shown at 50\% probability. Selected bond distances $(\AA)$ and angles $\left({ }^{\circ}\right)$ : XRD, Fe1-H42 $=1.56(2), \mathrm{B} 1-\mathrm{H} 42=1.21(2)$, Fe1-B1, 2.63(2), P2-Fe-P3 = 136.54(2); DFT predicted, Fe1-H42 = 1.51, Fe1-H43 = 1.50, $\mathrm{Fe} 1-\mathrm{H} 44=1.62, \mathrm{Fe} 1-\mathrm{H} 45=1.59, \mathrm{~B} 1-\mathrm{H} 42=1.24, \mathrm{Fe} 1-\mathrm{B} 1=2.63, \mathrm{H} 44-\mathrm{H} 45=0.84, \mathrm{P} 2-\mathrm{Fe} 1-$ $\mathrm{P} 3=140.63$. 


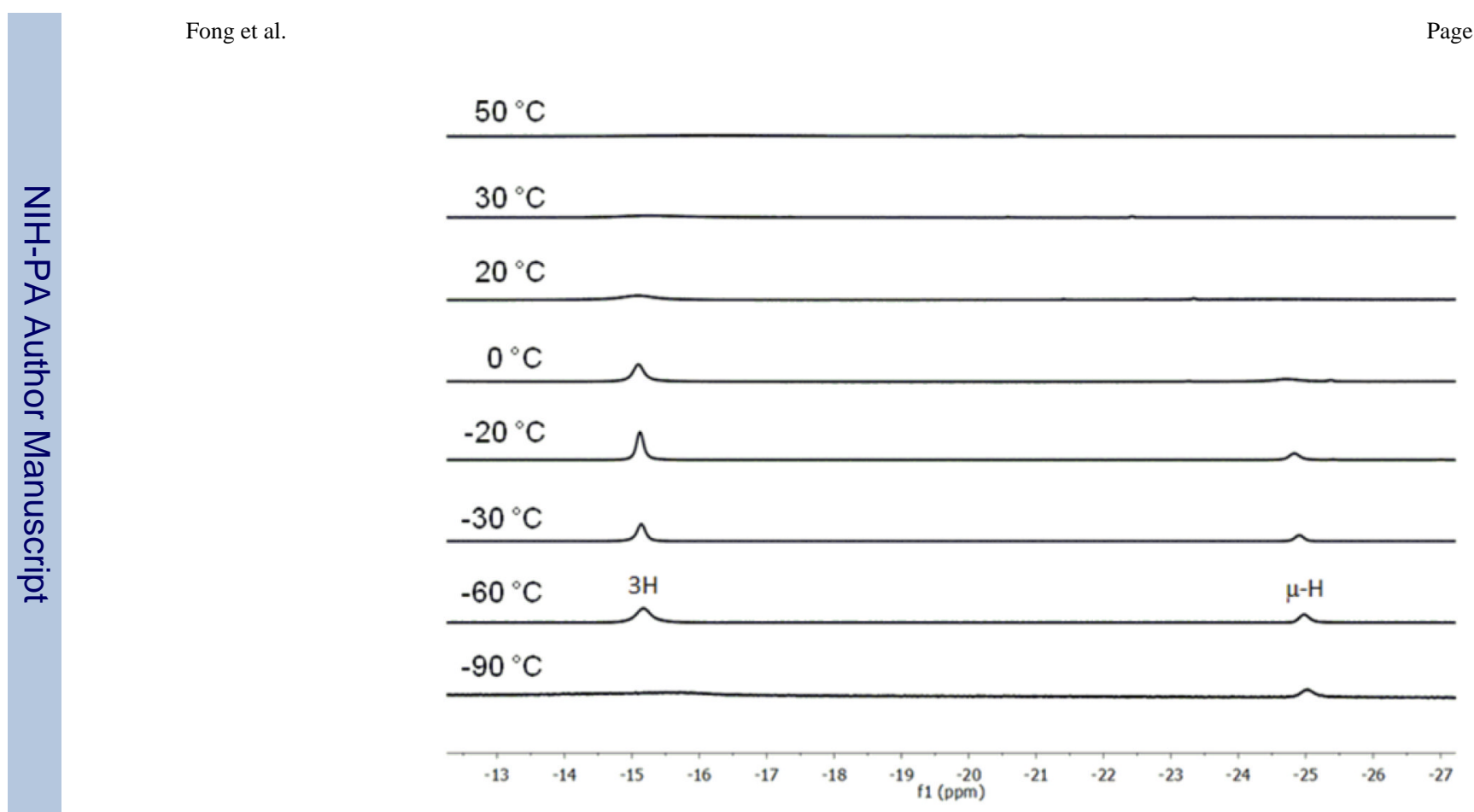

Figure 3.

${ }^{1} \mathrm{H}$ VT-NMR spectra of 3 in $d_{8}$-toluene under 1 atm of $\mathrm{H}_{2}$. 

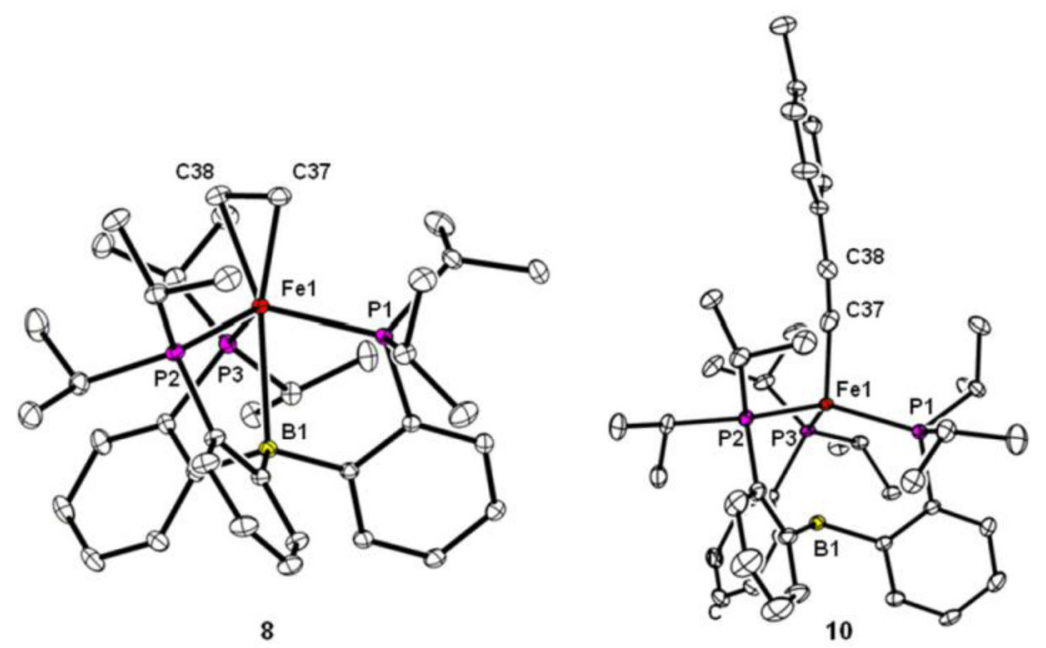

Figure 4.

XRD structures of $\mathbf{8}$ (left) and $\mathbf{1 0}$ (right). Ellipsoids shown at 50\% probability. Selected bond distances $(\AA)$ and angles $\left({ }^{\circ}\right): 8$ (average for two molecules in the asymmetric unit cell), Fe1-B1 = 2.491(1), Fe1-C37 = 2.103(1), Fe1-C38 = 2.113(1), C37-C38 = 1.397(2), $\Sigma(\mathrm{P}-\mathrm{Fe}-$ $\mathrm{P})=338.76(3) ; 10$ (average for two molecules in the asymmetric unit cell), $\mathrm{Fe} 1-\mathrm{B} 1=$ 2.761(2), Fe1-C37 = 1.918(2) C37-C38 = 1.169(3), $\Sigma(\mathrm{P}-\mathrm{Fe}-\mathrm{P})=345.07(2)$. 

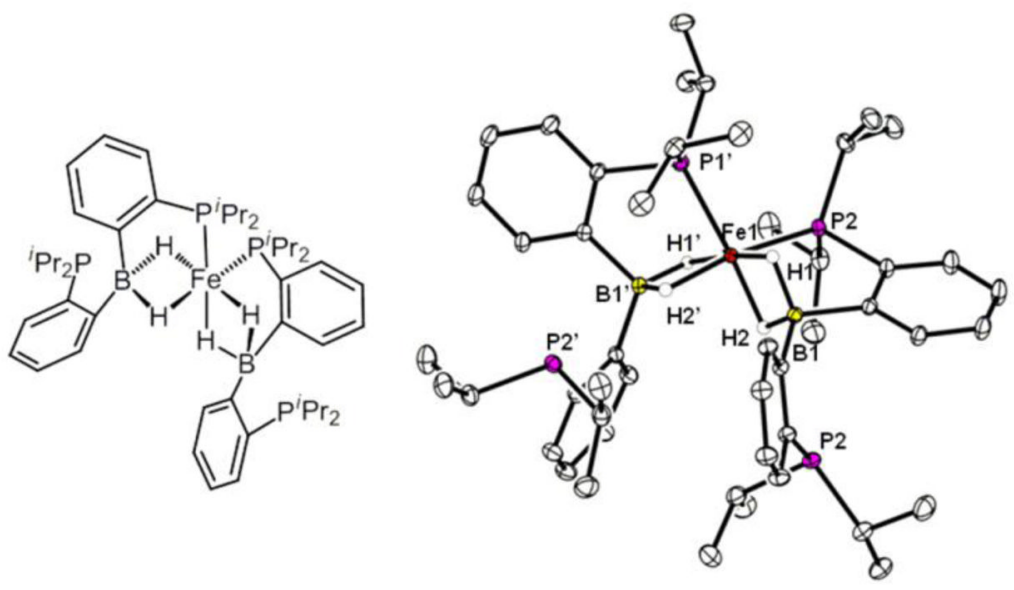

Figure 5.

Chemical line representation and XRD structure of 11. Ellipsoids shown at $50 \%$ probability. Selected bond distances $(\AA)$ : Fe1-H1 = 1.59(1), Fe1-H2 = 1.63(1), Fe1-B1 = 2.0900(6), Fe1$\mathrm{P} 1=2.2481(2)$. 

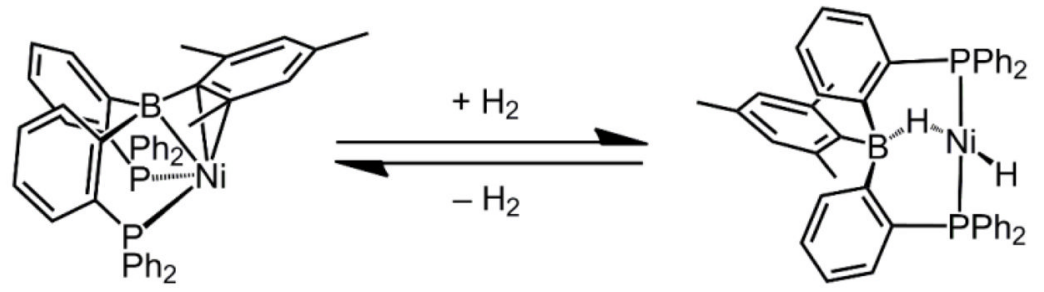

Scheme 1.

Related $\mathrm{H}_{2}$ Activation Across a Ni-B Bond 


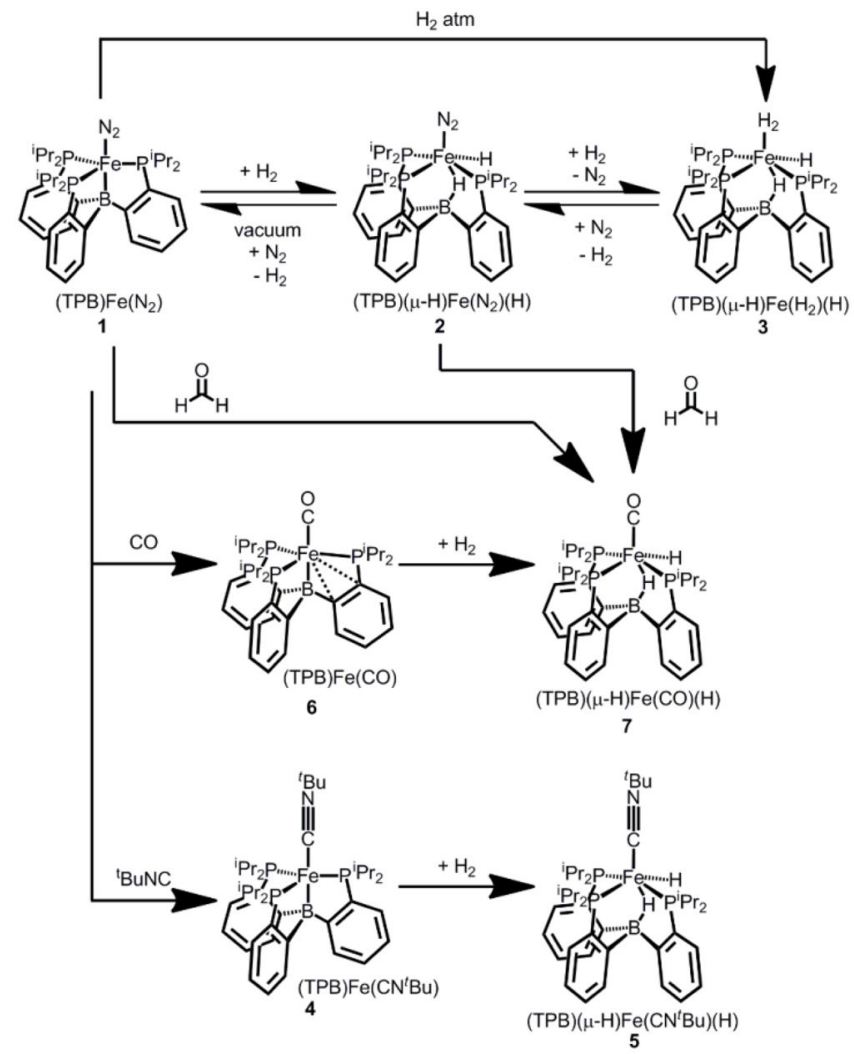

Scheme 2.

$\mathrm{H}-\mathrm{H}$ and E-H Bond Activations Across Fe-B Bonds 

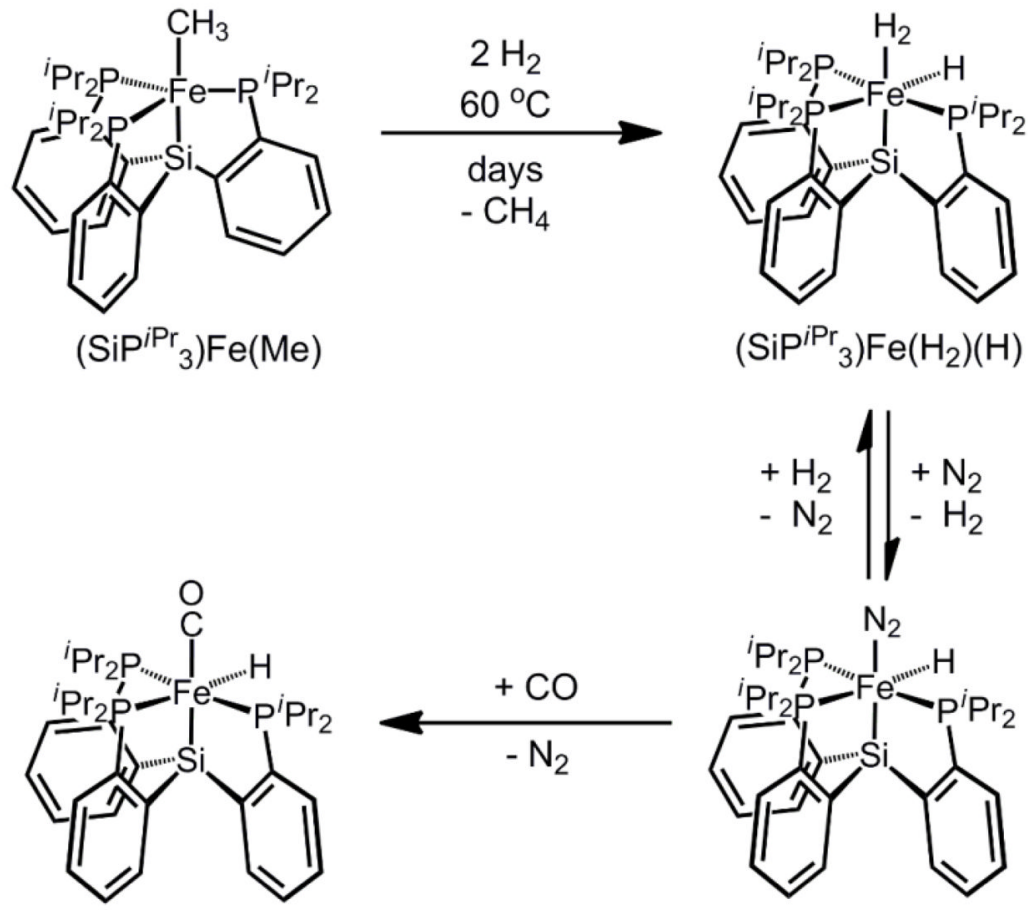

$\left(\mathrm{SiP}_{3} \mathrm{Pr}_{3}\right) \mathrm{Fe}(\mathrm{CO})(\mathrm{H})$

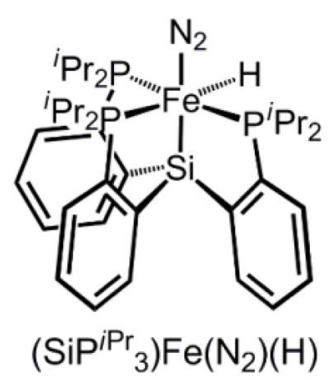

Scheme 3.

Chemistry of the Related Silatrane System 


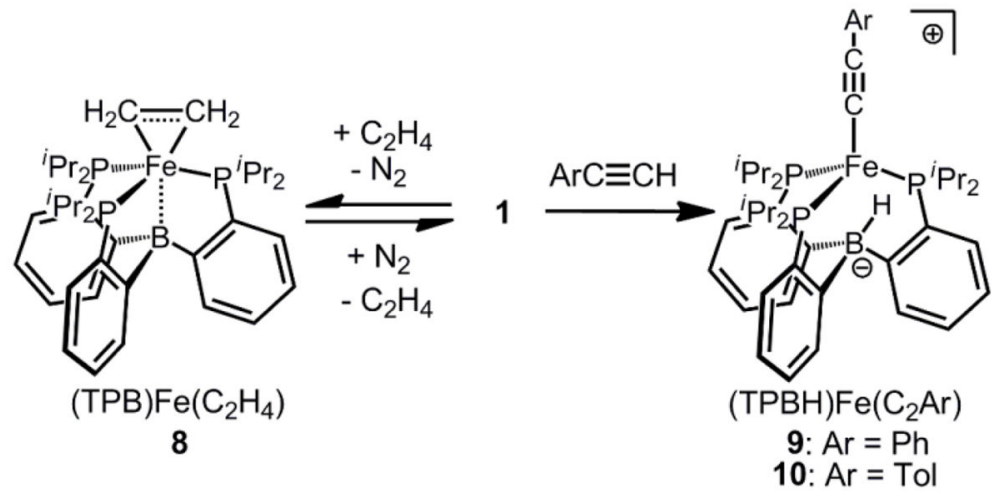

Scheme 4.

Ethylene Coordination and Arylacetylene C-H Bond Activation by $\mathbf{1}$ 

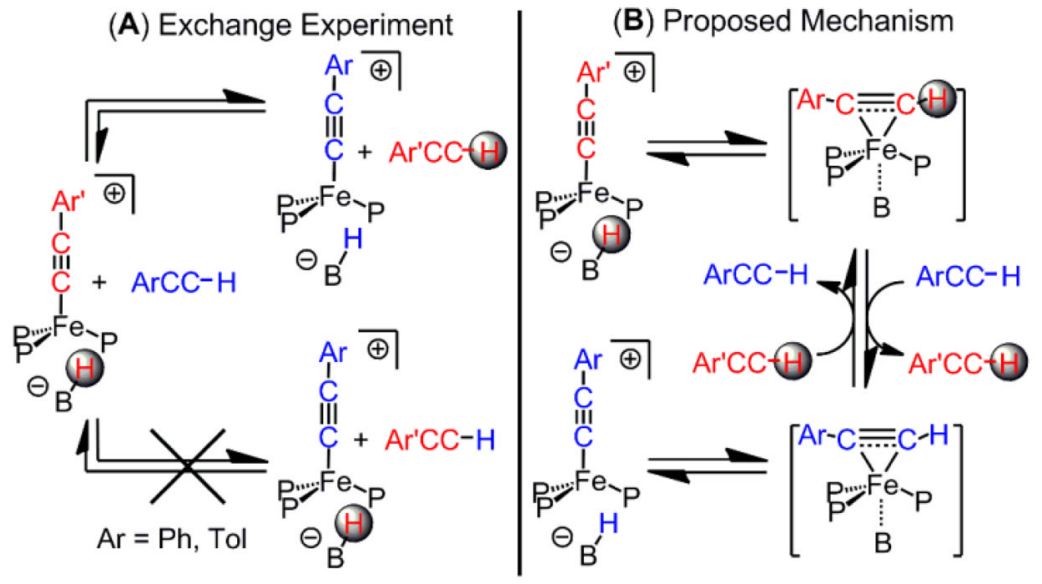

Scheme 5.

Reversible Arylacetylene C-H Bond Activation 


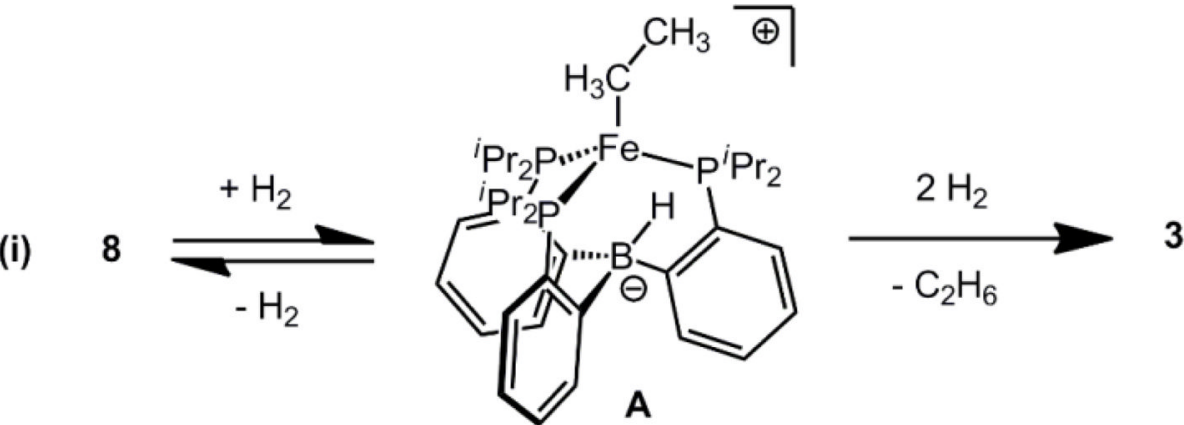

(ii)

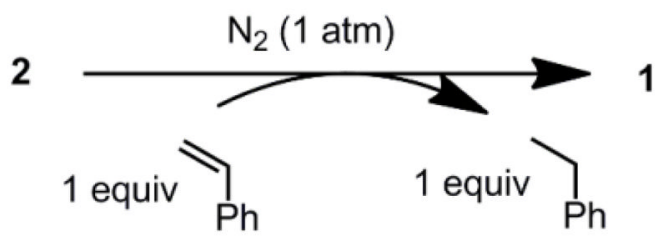

(iii)

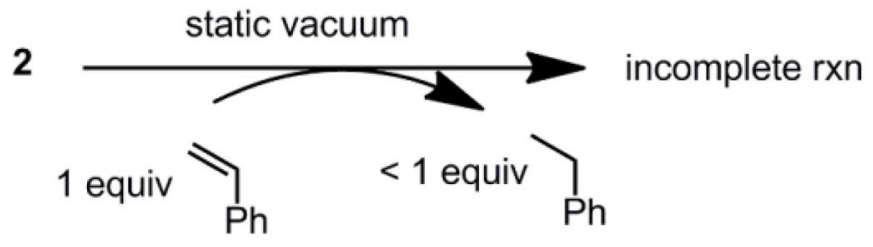

Scheme 6.

Stoichiometric Hydrogenation Reactions 


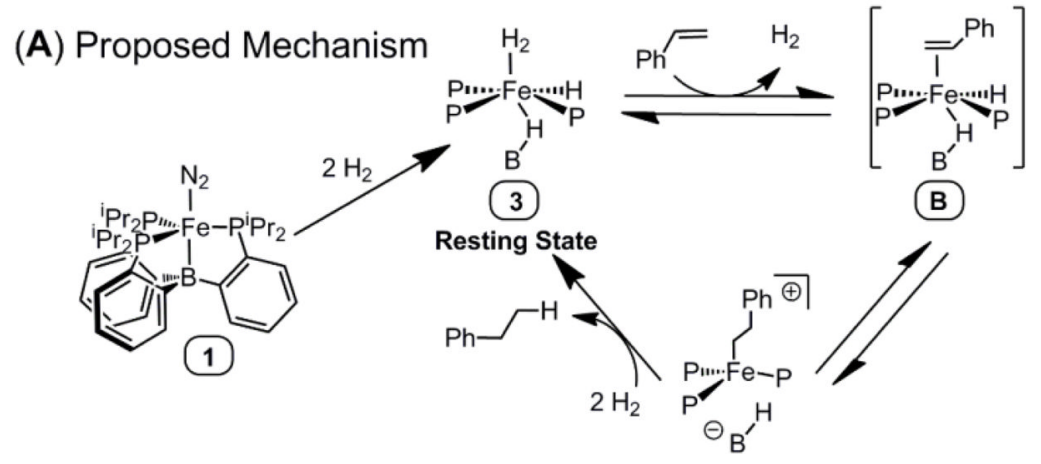

A

(B) Possible Elimination

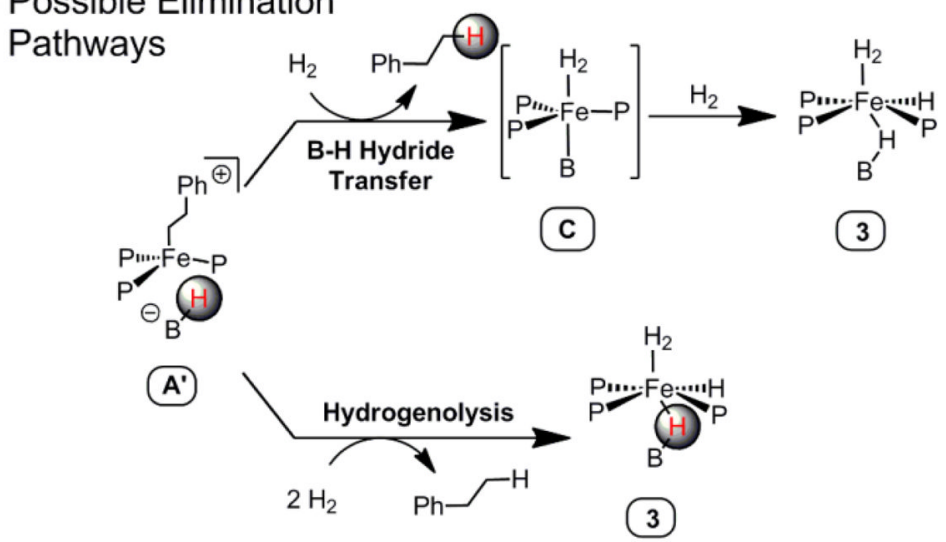

Scheme 7.

Mechanism and Alkane Elimination Pathways 


\section{Table 1}

Catalytic Hydrogenations by 1 with $\mathrm{H}_{2}$

\begin{tabular}{cccc}
\hline Precatalyst & Substrate & Product & TOF $\left(\mathbf{h}^{\mathbf{1}}\right)$ \\
\hline 1 & Ethylene $^{a}$ & Ethane & 15 \\
1 & Styrene $^{a}$ & Ethylbenzene & 0.27 \\
1 & Phenylacetylene $^{b}$ & Ethylbenzene & 0.16 \\
\hline
\end{tabular}

Conditions: Room temperature, $0.01 \mathrm{M} \mathrm{1,1}$ atm $\mathrm{H}_{2}$, and $0.01 \mathrm{M}$ ferrocene as an internal integration standard in $d_{6}$-benzene.

$a_{0.3 \mathrm{M} \text { substrate, }}$

$b_{0.29 \mathrm{M} \text { substrate. }}$

${ }^{c}$ As determined by ${ }^{1} \mathrm{H}$ NMR spectroscopy at $>95 \%$ product. 